\title{
Measuring Multifunctional Agricultural Landscapes
}

\author{
Bingjie Song, Guy M. Robinson * ${ }^{-10}$ and Douglas K. Bardsley \\ Department of Geography, Environment and Population, School of Social Sciences, University of Adelaide, \\ Adelaide, South Australia 5005, Australia; bingjie.song@adelaide.edu.au (B.S.); \\ douglas.bardsley@adelaide.edu.au (D.K.B.) \\ * Correspondence: guy.robinson@adelaide.edu.au
}

Received: 15 July 2020; Accepted: 31 July 2020; Published: 3 August 2020

\begin{abstract}
Multifunctional agriculture (MFA) has attracted increased attention from academics and policymakers in recent years. Academic researchers have utilised various approaches to assess and measure the multifunctionality of agriculture and rural landscapes. This paper outlines the nature of MFA and key supporting policies, before reviewing the applied research approaches, drawing primarily from the European Union and China where specific policies on MFA have been implemented to support rural development and promote sustainable rural communities. Four distinct types of valuation of modern MFA are recognised: economic, biophysical, socio-cultural, and holistic. Following a search of both the recent and older MFA literature, evaluations of the strengths and weaknesses of quantitative, qualitative, and mixed methods applications are provided using examples from a range of recent studies. The review illustrates the diversity of approaches to measure MFA. While noting that many studies operate at a landscape scale, the challenge remains that the lack of commonality in the research approaches applied means it is difficult to provide effective comparisons between studies or to compare findings. A future research agenda will need to emphasise the need for more consideration of the roles of MFA research to support decision-makers, especially policy makers, but also farmers who largely make decisions for individual farms but, if considered collectively, can transform production systems at a landscape scale.
\end{abstract}

Keywords: multifunctionality; agriculture; landscape; ecosystems; rural development

\section{Introduction-Multifunctional Agriculture (MFA)}

The explicit recognition that agriculture plays various roles in addition to the production of food and fibre, and so contributes to the development of multifunctional landscapes, first appeared in the academic literature in the 1970s [1-3]. For example, Smith and Raitz [4], in writing about rural development in Kentucky's Bluegrass region, refer to multifunctional agricultural estates producing various commodities, especially Burley tobacco, thoroughbred racehorses and purebred beef cattle, and contributing in numerous ways to rural life and economy. The concept has an extensive history, with many landed estates in Europe and North America from medieval times and colonial farms in Latin America, Africa and Asia not only representing centres of production of multiple agricultural commodities but also of craft goods (e.g., leather, wood and wool), while supporting villages and community life, as acknowledged by Carter [5], Chevalier [6], and Martins and Wade [7] among others. Indeed, some would argue that agriculture has always been multifunctional, but what is new is that an increasing public demand for alternative and non-commodity outputs can now be identified. Despite the important links between multifunctional agriculture (MFA), socio-cultural evolution and landscape development, the field has been a relatively neglected aspect of academic study until only recently, and it is still developing conceptual and procedural norms.

That neglect has also applied to policy formulations where the potential of MFA to contribute to multiple desirable modern rural development outcomes has only begun to be appreciated in the last 
three decades. However, there have been a growing number of theoretical (e.g., [8-10]) and case study examinations (e.g., [11-14]) on the nature of MFA and its contributions to economy, society, agricultural landscapes and the environment, and of direct relevance to this paper, on how it can be assessed and measured. In this state-of-the-art review, we briefly summarise some of the key ideas and policies pertaining to MFA and then present a structured critical review of the various approaches employed in formally measuring MFA, endeavouring to develop understanding of its contribution to the multiple roles played by agriculture in rural areas. Because of the well-developed and explicit policy focus on MFA in both the European Union (EU) and China, the paper concentrates on providing examples from work conducted in those two jurisdictions while acknowledging that MFA is present elsewhere, often without targeted policy support.

\section{The Nature of MFA}

In the late 1980s, the Commission of the European Communities [15], in its publication the future of rural society, emphasised that agriculture can generate a range of contributions to the character of rural areas, including economic development, environmental management and the viability of rural communities. This was the first formal official acknowledgement of MFA and it was followed subsequently in The Earth Summit held by the United Nations in 1992, in which Article 14 of Agenda 21 recognised and highlighted the existence and importance of MFA, thereby propelling MFA onto the international stage [16]. In 1993, the European Council for Agricultural Law officially introduced the term 'multifunctional agriculture' to provide legislative support for the development of agricultural sustainability ([10], p. 183). Despite these official statements regarding MFA, the notion of MFA has given rise to different understandings by researchers and institutions in different contexts-and not all jurisdictions have been supportive of the concept.

It is possible to recognise two distinct discourses. The first was summarised in 1997 in a 'European model of agriculture' proposed by a leading interest group for European farmers. This asserted, "in addition to its production function, agriculture has more functions such as protecting the natural environment, maintaining rural landscape and laying the foundation for rural development" [17]. This notion portrays a versatile agricultural system that responds to different social, ecological and economic drivers-a concept that was given greater focus in a second interpretation made in the Declaration of the Agricultural Ministers Committee of the Organisation of Economic Co-operation and Development (OECD) [18], which defined MFA as: "Beyond its primary function of producing food and fibre, agricultural activity can also shape the landscape, provide environmental benefits such as land conservation, the sustainable management of renewable natural resources and the preservation of biodiversity, and contribute to the socio-economic viability of many rural areas." This definition also recognised that MFA generates both private and public goods, stressing that some functions of agriculture represent joint forms of production and require government intervention to protect or enhance those activities [19]. This second interpretation provides a clear indication that agriculture is capable of both drawing from and contributing to a 'triple bottom line' of sustainable rural development, with economic, social, and environmental components [20]. Hence, agriculture is recognised as not just an economic activity producing food and fibre, but also providing many goods and services, including non-marketed, non-commodity, non-excludable and non-rival outputs [21].

In association with global initiatives, over the last two decades MFA has featured prominently in policy discourse, most notably in EU rural development policy in which agriculture has been encouraged to deliver various economic, social, and environmental outcomes. Since 2000, there has been a pronounced shift in the focus of the EU's Common Agricultural Policy (CAP) in favour of MFA, especially emphasising farmers' roles as landscape managers to maintain biodiversity and landscape aesthetics [22,23]. Agriculture is increasingly viewed as a key tool for reducing the impacts of climate change and for strengthening 'green growth' after the Global Financial Crisis [24]. Although MFA has rarely featured prominently or explicitly in rural development policies in North America or Australasia [25-28], it has also become a major element in policy initiatives in China since 2007, both as 
a means of contributing to rural poverty alleviation and delivering sustainable development. China's 2018 Rural Revitalisation Strategy targets expansion of the 'multiple functions of agriculture' [29], in part to generate more balanced development between the cities and the countryside [30].

MFA contributes to all three dimensions of sustainability, but to be considered systematically, it must facilitate the reconfiguration of resources in rural areas beyond an individual farm ([31], p. 423). In other words, while restructuring may be implemented by individual farmers, in a process termed agricultural or farm diversification [32-35], changes occurring on a single farm would have to impact beyond the individual farm business and influence other rural stakeholders if they are to be considered part of the process of multifunctionality. While land management is performed at the farm scale [36], outcomes should create mutually reinforcing synergies and networks to generate multifunctionality across rural landscapes [37-39]. MFA is not solely dependent on government policies for its promotion. Rather, much MFA is developed 'organically' by farmers, for example, undertaking actions to enhance agri-biodiversity [40] or diversify into on-farm processing activities that generate additional employment, build on cultural understandings and add to the strength of the rural economy [41,42].

In the last two decades, researchers from different disciplines have been clarifying that MFA 'regimes' have purposes apart from food and fibre production, including commoditisation of the countryside, management of renewable natural resources, and landscape and biodiversity conservation, which together should contribute to the cultural integrity and socio-economic viability of rural areas $[43,44]$. Hence, numerous studies have acknowledged that agricultural activities are a combination of both nature and society [45], capable of generating multiple outputs and amenities (e.g., food; food processing; nature, water and energy services; recreation; and scenery) from individual farms or across agricultural landscapes $[46,47]$. Thus, in many cases, the production of multiple outputs from agricultural systems, which constitutes multi-functionality, often involves a reconnection of agriculture's often-dominant economic function to its ecological and social roots.

\section{Assessing and Measuring Multifunctionality}

\subsection{The Literature Search}

Since the concept of MFA was first proposed and researched, different disciplines including economics, geography, political economy, ecology, environmental science and sociology have worked to conceptualise the topic, concentrating on their different foci and contexts. Within this work, some researchers have attempted to assess and/or measure MFA in order to not only provide a better understanding of agriculture, rural economies, cultures and landscapes, but also to support decision-making processes and improve ways of managing the environment sustainably [48,49]. Therefore, while the assessment of MFA in terms of its functions, goods and services has been studied in different ways [50], focusing on different scales from the global to micro-scale plots [51], they have largely concentrated on specific functions related to specific disciplines, rather than aiming to develop multi-faceted or holistic analyses of multifunctionality. Four different perspectives can be identified in this body of work on MFA: three focusing primarily on single functions (i.e., the economy, the agri-environment and the socio-cultural), and one that is adopting a more comprehensive perspective.

The papers discussed below were selected using the Google Scholar and Scopus search engines to search for the literature related to the measurement and assessment of MFA. This search also enabled us to examine previous reviews, meta-analyses, and well-cited studies on this topic. The procedure employed is set out in Table 1, showing the keywords searched for relating to each of the four topics (economic, biophysical, socio-cultural, and holistic valuations). In the case of economic and biophysical valuations a two-stage process was employed to enable the literature relating to particular methods and models to be investigated. The search enabled an inclusion of papers in which measurements were applied to a range of different functions and others where the focus was primarily on measuring 
a single non-productivist function of agriculture. In total 195 publications published since 2015 were generated by the search, in addition to just over 70 older, key publications. In the following analysis we focus on the former as we feel these provide the best indication of the direction of contemporary research approaches to measure MFA.

Table 1. Searches for the literature on measuring/assessing multifunctional agriculture (MFA).

\begin{tabular}{|c|c|c|}
\hline Topic & Step 1 Keywords & Step 2 Keywords \\
\hline $\begin{array}{l}\text { Economic } \\
\text { Valuation }\end{array}$ & $\begin{array}{l}\text { multifunctional agriculture } \\
\text { economic quantifying }\end{array}$ & $\begin{array}{l}\text { Contingent Valuation Method agriculture } \\
\text { Willingness to Pay agriculture } \\
\text { Choice experiment approach agriculture } \\
\text { Stated preference approach agriculture }\end{array}$ \\
\hline $\begin{array}{l}\text { Biophysical } \\
\text { Valuation }\end{array}$ & $\begin{array}{c}\text { ecological evaluations }+ \\
\text { agriculture } \\
\text { biodiversity evaluation }+ \\
\quad \text { agriculture } \\
\text { ecosystem services }+ \text { multi- } \\
\text { functional agriculture }\end{array}$ & $\begin{array}{l}\text { HSI model agriculture } \\
\text { InVEST agriculture } \\
\text { SoLVES agriculture } \\
\text { MaxEnt agriculture }\end{array}$ \\
\hline $\begin{array}{l}\text { Socio-cultural } \\
\text { Valuation }\end{array}$ & $\begin{array}{l}\text { quantify social functions + agriculture } \\
\text { qualify social functions + agriculture } \\
\text { quantify cultural functions + agriculture } \\
\text { qualify cultural functions + agriculture } \\
\text { assess socio-cultural agriculture } \\
\text { valuate social functions + agriculture } \\
\text { valuate cultural functions + agriculture }\end{array}$ & \\
\hline $\begin{array}{l}\text { Holistic } \\
\text { Valuation }\end{array}$ & $\begin{array}{l}\text { quantify holistic multifunctional agriculture } \\
\text { qualify holistic multifunctional agriculture } \\
\text { assess holistic multifunctional agriculture }\end{array}$ & \\
\hline
\end{tabular}

\subsection{Previous Surveys}

Our survey of the literature on approaches used to measure MFA revealed several previous overviews or meta-analyses of MFA that have been produced since the 2000s. For example, Randall et al. [52,53] conducted a meta-analysis estimating economic value functions for the impacts of US agricultural conservation programs on water quality, wetlands, and upland habitat and open space. The research reviewed had largely used willingness to pay (WTP) and environmental valuation databases, but the authors noted that lack of consistency in methodologies and inadequate specification of environmental descriptors made generalisations difficult (see also [19,54]). A more holistic consideration of MFA was undertaken by Sal and García [55], who reviewed a large volume of research, examining the link between the agri-ecosystem and sustainability for production, economic, biophysical, and socio-cultural functions of agriculture in Spain. The value of each dimension of sustainability was assessed using a semi-quantitative procedure as part of what they termed "a multi-dimensional evaluative model." Maduereira et al. [56] focused on economic valuations of non-commodity outputs from MFA, identifying two approaches. One comprised pricing outputs according to their provision costs, through cost-side methods, which included costs of replacement, restoration, relocation, and government payments. These approaches fail to provide information about individual demand regarding the goods and services available. Hence, demand-side economic valuation methods (i.e., the estimation of individual demand for non-market goods) were deemed preferable, notably those reliant upon estimates of the WTP or the consumer surplus related to a change in the provision level of a given output. These methods are based on two alternative approaches: revealed preference methods and stated preference methods, which are discussed further below in Section 3.3.1.

More recent overviews include that by Ahtiainen et al. [57], who examined 34 studies addressing the relative importance of agricultural policy objectives for different stakeholder groups. They considered the preferences of citizens, farmers, and experts for economic, social, and environmental dimensions of MFA, paying special attention to agri-environmental objectives. In their broad study, they noted that the general public emphasised social values, whereas experts and farmers placed more 
weight on economic objectives (see also [58]). Huber and Finger [59] performed a meta-analysis of the WTP for cultural services from grasslands in Europe based on 32 research papers. A proposed switch from cropland to grassland reduced WTP, while an increase in less-intensive land use in mountain regions raised WTP but by a smaller amount than the reduction.

Lee et al. [60] examined the impact of conservation farming practices (e.g., conservation agriculture) on the provisioning of Mediterranean agri-ecosystem services via a meta-analysis of 155 published case studies. They quantified the effect of various management options on four provisioning and four regulating ecosystem services (ESS), rather than directly examining the impacts on MFA. The relationship between ESS and MFA is discussed further in Section 3.3.2. Overall, alternative agriculture management practices led to more positive than negative effects on ESS across the region. Van Zanten et al. [61] also focused on ESS, at the landscape scale in the EU, assessing the benefits delivered by ESS by means of a monetary or social valuation via a survey of the relevant literature. They comment on the lack of suitable methods available for studying the connections between the different components of the ecosystem. Wittering et al. [62] continue this argument, noting that there are often terminological issues that affect multi-component evaluations of the agri-ecosystem.

García-Martín et al. [63] explicitly focused on multifunctional landscapes in their survey of integrated landscape initiatives in Europe. Rather than attempting to measure MFA, they focused on management approaches, acknowledging that the most relevant characteristics of such initiatives are a holistic approach, emphasising the involvement and coordination of different sectors and stakeholders at many levels, especially their roles as agents of awareness raising and learning about MFA. Land management was also at the heart of van Vliet et al.'s [64] survey of 137 studies of agricultural land use change in Europe, which focused on whether intensification or disintensification was occurring. MFA was not a specific target of this research, but elements of multifunctionality were related to the two poles of change, such that intensification involved specialisation and a decrease in landscape elements, whereas disintensification generally meant more landscape elements and farm diversification. Meanwhile, Kizos et al. [65] focused on the cultural functions of multifunctionality in Europe, reviewing three sets of literature on the driving forces of landscape change, on rates of landscape change and on landscape actors. This was linked to another review of cultural ESS by Plieninger et al. [66]. None of these reviews sought to measure MFA themselves, but they charted the spatial dynamics of landscape change, illustrating where different processes (e.g., intensification, land abandonment) were most dominant and considering what policies could be developed to best protect and manage multifunctional systems and landscapes.

\subsection{Measuring MFA}

In producing the review detailed below, we grouped individual studies into four categories using interpretations based on the reading of the abstract, introduction and conclusion. We fully acknowledge that this is not a definitive process of classification and that there are some studies in which there may be some blurring between different categories, such as an assessment that primarily examines cultural functions but includes some broader economic considerations. In selecting exemplar references we have tried to use illustrations where the allocation of the study to a given category is clear-cut, but we accept that there is a degree of subjectivity in this process. The result is an initial review that highlights the principal means of measurement and assessment of MFA associated with four dominant valuation categories. We also include a short Section 3.4 after these valuation categories that discusses relational values, as these represent work on multifunctional landscapes that sits in the space between ecological and economic values.

Table 2 shows the results of the keywords search. These results are now examined in turn to illustrate the different research interests and concerns that have been associated with MFA, focusing primarily on how to assess and measure multifunctionality. 
Table 2. Summary of approaches and methods used in assessing and measuring MFA.

\begin{tabular}{|c|c|c|}
\hline Approach & Methods & Exemplar References \\
\hline \multirow[t]{2}{*}{ Economic } & $\begin{array}{l}\text { Stated-preference method (using } \\
\text { contingent valuation, willingness } \\
\text { to pay, choice experiments, } \\
\text { conjoint analysis) }\end{array}$ & $\begin{array}{l}\text { Alcon et al. [67]; Bernués et al. [68]; Chen et al. [69]; } \\
\text { Dupras et al. [70]; Jung [71]; Kubíčková [72]; Mazzocchi and } \\
\text { Sali [73]; Nambuge et al. [74]; Novikova et al. [75]; Ohe [76]; } \\
\text { Ragkos and Theodoridis [77]; Sangkapitux et al. [78]; } \\
\text { Tagliafierro et al. [79]; Torres-Miralles et al. [80] 2017; } \\
\text { van Zanten et al. [81]; Vivithkeyoonvong and Jourdain [82] } \\
\text { 2017; Sejati et al. [83]; Zabala et al. [84]; Zhao and Huang. [85] }\end{array}$ \\
\hline & $\begin{array}{l}\text { Revealed preference method } \\
\text { (using hedonic pricing, estimated } \\
\text { travel costs) }\end{array}$ & $\begin{array}{l}\text { Baum and Kozer-Kowalska [86]; Dong et al. [87]; Huang and } \\
\text { Wang. [88]; Münch et al. [89] }\end{array}$ \\
\hline \multirow{6}{*}{ Biophysical } & Ecological footprint & Blasi et al. [90] \\
\hline & Ecosystems services & Ketema et al. [91]; Yu et al. [92] \\
\hline & Experiment based model & Aneva et al. [93] \\
\hline & $\begin{array}{l}\text { Generalised linear mixed model } \\
\text { (GLMM) }\end{array}$ & $\begin{array}{l}\text { Lecina-Diaz et al. [94]; Lefcheck et al. [95]; Liu et al. [96]; } \\
\text { Puig-Montserrat et al. [97]; Rollin et al. [98] }\end{array}$ \\
\hline & InVEST model & $\begin{array}{l}\text { Bhagabati et al. [99]; Dai et al. [100]; Du and Rong [101]; } \\
\text { Goldstein et al. [102]; Ma et al. [103]; Pham et al. [104]; } \\
\text { Polasky et al. [105] }\end{array}$ \\
\hline & $\begin{array}{l}\text { Models based on biophysical } \\
\text { character }\end{array}$ & $\begin{array}{l}\text { Belem and Saqalli. [106]; Ma et al. [107]; Mattsson et al. [108]; } \\
\text { Peng et al. [109]; Peng et al. [110]; Peng et al. [45]; } \\
\text { Rallings et al. [28] }\end{array}$ \\
\hline \multirow{10}{*}{ Socio-cultural } & Assessment of aesthetics/scenery & Tenerelli et al. [111]; Williams [112] \\
\hline & Choice experiment method & Rewitzer et al. [113] \\
\hline & Cultural ecosystem services & Bullock et al. [114] \\
\hline & Landscape indicators & Vlami et al. [115]; Willemen et al. [116] \\
\hline & MaxEnt model & He et al. [117] \\
\hline & Monetisation & Chen et al. [118] \\
\hline & Multi-criteria assessment & Bonenberg [119] \\
\hline & Participatory approach/Interviews & $\begin{array}{l}\text { Bernués et al. [120]; Darvill and Lindo [121]; Gosal et al. [122]; } \\
\text { Hahn et al. [123]; Junge et al. [124]; Kvakkestad et al. [125]; } \\
\text { Plieninger et al. [126]; Plieninger et al. [127]; Schmidt et al. [128]; } \\
\text { Schirpke et al. [129]; Schirpke et al. [130]; } \\
\text { Soy-Massoni et al. [131]; Tulla et al. [132]; } \\
\text { Villegas-Palacio et al. [133]; Włodarczyk-Marciniak et al. [134]; } \\
\text { Yang et al. [135]; Zoderer et al. [136] }\end{array}$ \\
\hline & SolVES model & $\begin{array}{l}\text { Bogdan et al. [137]; Qin et al. [138]; Semmens et al. [139]; } \\
\text { Sherrouse et al. [140]; Wang et al. [141] }\end{array}$ \\
\hline & Visualisation methods & Bachi et al. [142]; Oteros-Rozas et al. [143] \\
\hline \multirow{8}{*}{ Holistic } & Analytic hierarchy process (AHP) & $\begin{array}{l}\text { Carmona-Torres et al. [144]; Gu et al. [145]; Johansen et al. [146]; } \\
\text { Rovai and Andreoli [147]; Sajadian et al. [148]; Sousa et al. [149] }\end{array}$ \\
\hline & Delphi method & Shipley et al. [150] \\
\hline & Ecosystems services (ESS) & Song et al. [151] \\
\hline & Emergy valuation & Dai et al. [152] \\
\hline & Indicators & Zhang et al. [153] \\
\hline & Monetisation & $\begin{array}{l}\text { Damani [154]; Fagioli et al. [155]; Fleskens et al. [156]; Hrabák } \\
\text { and Konečný [157]; Marques-Perez and del Río et al. [158]; } \\
\text { Modernel et al. [159]; Nguyen et al. [160]; } \\
\text { Stürck and Verburg [39]; Troiano et al. [161]; Zhang et al. [162] }\end{array}$ \\
\hline & Multi-criteria assessment & $\begin{array}{l}\text { Li et al. [163]; Marques-Perez and Segura., [164]; } \\
\text { Schaller et al. [165] }\end{array}$ \\
\hline & Participatory approach (PPGIS) & $\begin{array}{l}\text { Fagerholm et al. [166,167]; García-Nieto et al. [168]; } \\
\text { Kivinen et al. [169]; Verbrugge et al. [170] }\end{array}$ \\
\hline
\end{tabular}




\subsubsection{Economic Valuation}

Evaluating the economic functions of agriculture in the context of MFA generally means that the economics of the production of food and fibre are de-emphasised. These 'standard' outputs, which appear in a farmer's balance sheet, are largely superseded in the MFA literature by demand-side, non-market valuations of public goods, derived from neo-classical economics, which are goods and services insufficiently provided in commercial markets and/or goods, services and attributes valued as beneficial to the public (e.g., biodiversity, landscape, rural economic vitality, food security, cultural heritage). Consequent on the "drive to increase the production of food, feed, timber, energy and other marketed commodities from land over the past half century" these public goods may be under-supplied ([171], p. 6). In various parts of the world, but especially the EU, this lack of supply has been used as a justification for moving farm support policies away from the production of food and towards the provision of a range of environmental and social benefits from agriculture.

The valuation of public goods derived from MFA has proved problematic. First, public goods cannot be exchanged in a market unless exchangeable property rights are defined for them, and second, how various assets are valued may differ according to circumstance and whether they can be owned and traded. Public goods also exhibit 'jointness' in that they are a by-product of farming's production of marketed goods, which may complicate efficient policy design.

Assessing the economic value that consumers assign to non-commodity outputs has been tackled by employing demand-side valuation methods, which provide estimates of the WTP or the consumer surplus associated with a change in the provision level of a given output, based on either a revealed preference or a stated preference method. The former uses hedonic pricing (estimating the demand for a good) or travel costs as a proxy. Stated preferences are investigated using contingent valuation methods (CVM), choice experiments and conjoint analysis if there is a variety of goods and services under consideration.

Classical valuation studies often involve CVM and WTP. In this approach, values are assigned by constructing demand curves reflecting survey respondents' reactions in choice experiments. Scenarios can reflect the provision or withdrawal of specific benefits. An alternative is the use of hedonic pricing approaches, in which values are inferred from indirect expenditure choices (such as travel costs used as a proxy for valuation of specific sites or locations by a surveyed group, or house prices used to reflect a perceived higher or lower quality of a certain locale). A major criticism of such economic valuations relates to inherent difficulties in applying these techniques, the high sensitivity of results to underlying assumptions, their subjectivity and the design and conduct of choice experiments ([171], p. 13, [172]).

Many economic approaches to MFA utilise the notions of joint products (multiple products generated simultaneously by a single production process), private and public goods, and the positive and negative externalities that are produced and derived from the rural economy $[173,174]$. These approaches have been widely used in Europe in the last decade $[155,175,176]$, especially to assess the economic aspects of the implementation and operation of the CAP. Within this context, CVM is often applied (e.g., [71,75,77]) as a survey-based economic technique for the valuation of non-market resources, such as biodiversity conservation or the control of soil and water contamination $[177,178]$. For example, Kallas et al. [179] integrated this method and the analytical hierarchy process (a structured technique for organising and analysing complex decisions, based on mathematics and psychology) to demonstrate the importance of the various functions of agriculture in Spain based on farmers' socio-economic characteristics. Similarly, Howley et al. [180] explored WTP for protection of agricultural activities in the United Kingdom (UK), demonstrating wide public support for the protection of traditional farm landscapes, and hence also for the second pillar of the CAP that supports sustainable agricultural responses to the economic, environmental and societal challenges of the 21st century.

CVM provides quantitative information about the demand for agricultural landscape services, which can then be used to improve agri-environmental policy. Novikova et al. [75] conducted an empirical study in Lithuania using CVM, highlighting that local residents primarily valued the maintenance and preservation of the agricultural landscape, indicating that the externalities of 
agriculture should be regarded as crucial in evaluating farmers' performance. A more nuanced evaluation of the agricultural landscape was presented by Ragkos and Theodoridis [77], employing a choice experiment approach to probe non-traded functions provided by Cypriot agriculture. This showed that environmental protection, cultural heritage, and stability of agricultural trade were most important to farmers on the island, with MFA presenting complicated positive and negative influences on the local natural environment and social provision. Similar complexity appears in the work of Bernués et al. [68], who combined qualitative methods and a survey-based stated-preference method to determine the value of key market and non-market functions of agri-ecosystems in the Norwegian fjords and mountains, calculating a total economic value to reveal that the public attached great importance to the production and supply of quality food.

Some studies focusing on the assessment of MFA in Australia have also used economic methods, for example the work of Bennett et al. [181], showing that MFA does not only occur in developed countries with high population densities but can also be identified in situations with less population pressure on resource use. Various studies using economic valuation in the United States have focused on state- or county-level non-market functions, such as farmland amenity, environmental preservation, and aesthetic value [174]. These studies have included use of non-market evaluation techniques to measure amenity values generated by farmland [182] and public preferences for amenity and agricultural functions [183,184], applying WTP and CVM [185,186], and WTP for ecosystem services [187].

Similarly, researchers in Asia have exploited economic methods to quantify MFA. This has frequently involved using choice experiment models where a finite number of alternatives comprise hypothetical choice situations, called choice sets; each respondent chooses the preferred alternative for each choice set. Latent class choice models have also been popular in which the choice probability is calculated, where an individual in a particular group chooses an alternative from a particular set of alternatives. For example, Sangkapitux et al. [78] used both choice experiment and latent class models to estimate the needs of Thai society for environmental services from agriculture and the WTP for various agricultural functions. Gao et al. [188] employed non-use WTP based on residents' ecological cognition in the Sanjiang Plain in China and indicated that distance from a specified feature, and recognition of and willingness to support certain environmental functions are closely related.

In general, economic methods have been widely used in the evaluation of multifunctionality, and research has gradually extended from a focus solely on quantitative assessments (see the review by Hölting [49]). Researchers have especially favoured methods such as CVM, WTP and choice experimental methods to reveal individuals' subjective feelings towards non-commodity outputs of agriculture (e.g., maintenance of rural landscape) to shed light on the values of public goods and externalities. In recent years, some scholars have also attempted to evaluate the cultural functions of agriculture using economic methods. For example, Rewitzer et al. [113], adopted a choice experiment method to evaluate cultural ecosystem services at a landscape scale in the Swiss Alps, showing that cultural landscape conservation was supported strongly by local citizens. Clearly, however, some functions of agriculture, such as food security or social cohesion, are difficult to analyse through economic valuations [43].

\subsubsection{Biophysical Valuation}

Biophysical valuation primarily focuses on ecology-related functions of agriculture and the analysis of ecosystem services (ESS). The focus has often been explicitly on the measurement and assessment of the ecological components of agri-ecosystems. Researchers have attempted to construct and employ various methods and models, including developing habitat suitability indices (HSI), integrated valuation of ESS and trade-offs (InVEST) models, assessing social values of ESS (SolVES), and using maximum entropy (MaxEnt) to extrapolate where data are absent [100]. Those methods used most frequently, such as HSI and InVEST, have been applied primarily to quantify habitat quality (Table 3), and the ecological contributions of MFA rather than broader holistic functions. Similarly, several researchers have applied the generalised linear mixed model (GLMM) to study biological 
diversity of agri-ecosystems $[95,97,98]$. However, in the last decade, the InVEST model has been widely applied because of its ability to incorporate quantified and spatially explicit measures of social values into ESS assessments using geographic information systems (GIS) [99,102,105]. It has also been combined with use of factor analysis [189], to broaden the scope of the research further.

Table 3. Habitat quality assessment models.

\begin{tabular}{|c|c|c|c|}
\hline Applied Model & Advantages & Disadvantages & Exemplar References \\
\hline $\begin{array}{l}\text { Habitat Suitability } \\
\text { Index (HSI) model }\end{array}$ & $\begin{array}{l}\text { This model is suitable for } \\
\text { expressing simple and easily } \\
\text { understood impacts of } \\
\text { interventions on targeted } \\
\text { species' distribution and } \\
\text { abundance, particularly } \\
\text { suitable for fish habitat. }\end{array}$ & $\begin{array}{l}\text { It is quite subjective and lacks } \\
\text { universality; it does not consider } \\
\text { interactions and correlations } \\
\text { between habitat } \\
\text { variables }[190,191] .\end{array}$ & $\begin{array}{l}\text { Duflot et al. [192] } \\
\text { Latifiana et al. [193] } \\
\text { Lewis et al. [194] } \\
\text { Martinig [195] } \\
\text { Steenweg et al. [196] } \\
\text { Tadesse et al. [197] } \\
\text { Zubizarreta-Gerendiain et al. [198] }\end{array}$ \\
\hline $\begin{array}{l}\text { Integrated } \\
\text { Valuation of } \\
\text { Ecosystem Services } \\
\text { and Tradeoffs } \\
\text { (InVEST) model }\end{array}$ & $\begin{array}{l}\text { The model is based on } \\
\text { ecological processes, flexible } \\
\text { parameter adjustment, spatial } \\
\text { expression of evaluation } \\
\text { results, time, space, } \\
\text { multi-service, and multi-target } \\
\text { trade-offs. }\end{array}$ & $\begin{array}{l}\text { Scope of application and } \\
\text { scalability are limited, and few } \\
\text { sub-modules are designed for } \\
\text { cultural services }[141,191] \text {. }\end{array}$ & $\begin{array}{l}\text { Aneseyee et al. [199] } \\
\text { Kija et al. [200] } \\
\text { Liu et al. [201] } \\
\text { Sallustio et al. [202] } \\
\text { Zhang et al. [203] } \\
\text { Zhong and Wang [204] }\end{array}$ \\
\hline $\begin{array}{l}\text { Maximum Entropy } \\
\text { (MaxEnt) model }\end{array}$ & $\begin{array}{l}\text { Developed originally to model } \\
\text { geographical distributions of } \\
\text { species [205], it uses } \\
\text { presence-only data, performs } \\
\text { well with incomplete data (via } \\
\text { extrapolation), and requires } \\
\text { only small sample sizes. }\end{array}$ & $\begin{array}{l}\text { Estimations of the amount of } \\
\text { error in its predictions are } \\
\text { limited. Extra care is needed } \\
\text { when extrapolating to another } \\
\text { study area. MaxEnt is not } \\
\text { available in standard statistical } \\
\text { packages [206-208]. }\end{array}$ & $\begin{array}{l}\text { Alfaya et al. [209] } \\
\text { Almasieh et al. [210] } \\
\text { Healy et al. [211] } \\
\text { Khosravi et al. [212] } \\
\text { Liu et al. [213] } \\
\text { Mammola et al. [214] }\end{array}$ \\
\hline
\end{tabular}

Biophysical valuation has supported research concentrating on relatively large scales, including counties, physical regions such as upland areas and river basins to quantitatively assess multiple biophysical functions of agriculture. A typical example is the research by Ma et al. [103], who combined an integrated cellular automata (CA)-Markov model and an InVEST model of habitat quality to discuss and explore the evolution of land cover and the values of biodiversity across an entire Chinese province from 1995 to 2015. They showed that biodiversity was being transformed from a degraded towards a hypothesised optimal state, with further gradual improvement predicted. A more typical Chinese example applying InVEST is the work of Dai et al. [100] who combined this model with the valuation of ESS and trade-offs to evaluate habitat quality based on watershed subdivisions in Northeast China from 1990-2010.

The term 'ecosystems services' (ESS) has become prominent in political discourse and academic research post-2000, especially with the publication of the Millennium Ecosystem Assessment (MEA) in 2005, which defined ESS as "the benefits people directly or indirectly obtain from the environment" [215]. Thus, ESS subsumes the multifunctional roles played by components of ecological systems, including agri-ecological systems, and comprises provisioning, regulating, supporting and cultural services [216]. There are ongoing problems with assessing ESS, as the concept itself conflates functions, services, and benefits [217]. However, usually a chain is conceptualised whereby natural assets generate functions that provide beneficial services to society, and which society may or may not explicitly value in various ways. The assets and the services may be valued using 'natural capital' social accounting [218], but there are numerous valuation methods. Moreover, the complexity of ESS makes it difficult to portray a simple relationship between single or multiple ESS and MFA, though it is possible to argue that agri-ecosystems (as an asset or product/function of agriculture) deliver various ecological services to beneficiaries.

Huang et al. ([219], p. 138), propose combining MFA with ESS in a common approach, arguing that "MFA considers functions as agricultural activity outputs and prefers farm-centred approaches, 
whereas ESS considers ecosystem functions in the provision of services and prefers service-centred approaches." Nevertheless, there have been several ESS studies relevant to MFA, especially those focusing on environmental benefits derived from agriculture and the socio-cultural aspects and values associated with agriculture that have drawn upon ESS in their assessments. A good example is that of Plieninger et al. [127], which examined the positive and negative associations of multiple ESS within farmland in Europe of high environmental value, but essentially focusing on cultural ESS. They concluded that the socio-cultural mapping of ESS is useful for understanding the perceived multifunctionality of a landscape.

A common means of valuing ESS is to employ payment for ecosystem services (PES), which can operate as a mechanism to translate external, non-market values into financial incentives for provision of services (e.g., carbon sequestration, cultural services, biodiversity), to public or private purchasers who can benefit from this provision [220]. Typically, PES focuses on one service or function to the exclusion of the system as a whole and multiple interactions between services [221]. Some valuations have been embedded in broader participatory planning processes. However, many have employed valuation techniques mirroring those used for public goods, notably hedonic and contingent valuation methods, whereby proxy measures consider the actual monetary cost of provision of a specific service via a non-ecosystem route. Alternatives for assessing cultural ESS have been developed more widely in recent years and mirror those for the cultural functions of MFA depicted in Table 2.

ESS analytical methods of the ecological functions of MFA have frequently been applied at the landscape level. For example, Yu et al. [92] combined data from a digital elevation model, vegetation data and remote sensing data using GIS-based AHP methods, to evaluate agricultural land suitability and ecological functions in the upper reaches of the Yangtze River. Analysis of agricultural landscapes via ESS similarly enabled Zhou et al. [222] to develop the concept of an 'agricultural functional spectrum', applying it to the study of trade-offs in ESS, using integrating methods including value assessment, diversity and structural measurement approaches to decipher trade-offs in agri-ESS in the rural hinterland of Xi'an.

Most large-scale studies solely evaluating biophysical functions of agriculture have ignored explicit considerations of human impacts and viewpoints. However, stakeholder involvement, especially that of farmers, is vital for comprehensive assessments of MFA. Hence, Ketema et al. [91] quantified ecological values of land use types with 90 criteria-based farmers' assessments and empirically analysed soil properties in Southern Ethiopia. The inclusion of active farmers' perceptions can validate results because the intangible ecological values of land use are considered by farmers in their day-to-day farm management. More examples of this approach are discussed under the 'holistic' category in Section 3.3.4 below.

There has been no unifying method to quantify MFA using a biophysical valuation approach [223]. In general, biophysical quantitative assessments of MFA are relatively mature in terms of their application to agri-forestry and grassland/pasture systems, while assessments of cultivated land and inland fisheries are under-developed. Moreover, the choices of specific methods, especially which models to use or the scale to which they are applied, have been quite eclectic. Often, different methods lead to quite different results, which raises questions about their accuracy or comparability [109]. Those limitations can hinder the effective application of MFA policy, especially when current methods do not enable accurate assessments of programs that involve public investment.

\subsubsection{Social-Cultural Valuations}

The agricultural landscape has been shaped by complex human-nature interactions, including many social and cultural functions that exist alongside the frequently more dominant economic functions. The assessments of such socio-cultural functions are often more complicated than economic dimensions, because of the dynamic interrelationships between farmers and societal actors, in association with the economic and physical environments [224,225]. Social and cultural functions refer to the value that society places on, and the services derived from MFA [77]. Agriculture often 
contributes to cultural heritage by framing the major social activities within rural areas, including the behaviours of farming families and communities and the generation of employment. It also often delivers social functions that maintain farming systems that generate landscape distinctiveness. However, due to the limitations and challenges of assessment methods, socio-cultural functions have often not been fully considered in the valuation of MFA [122].

Valuation of socio-cultural functions is typically based on cultural ESS, with most research methods comparable with those associated with calculating ESS at landscape and regional scales. In addition, some quantitative methods have been derived from environmental economics, dealing with market prices, travel costs and hedonic pricing, while observation, social media-based interviews, and participatory GIS can be recognised as common qualitative methods utilised [226]. Some researchers have examined the consumption of cultural functions by tourists, measuring this via money spent or charges levied for tourist attractions and enterprises [227]. Others have used assessments of landscape aesthetics and scenery by tourists to help evaluate cultural functions [111,112] or assessments by local residents as part of policy formulation [114].

There are many case studies from Europe that assess MFA's socio-cultural functions, because both the CAP and the EU Biodiversity Strategy to 2020 recognise the importance of cultural and social components in landscape evolution. Relevant studies have grown in recent years, with many focusing on the landscape or catchment scale [121,228,229]. For example, Willemen et al. [116] classified the agricultural landscape into seven functions (residential, intensive livestock, cultural heritage, tourism, plant habitat, arable production, leisure cycling) in Dutch rural areas, and employed landscape indicators to quantify and identify these functions (see also [146]). They observed the interrelationships among the functions and the impact of multifunctionality on individual functions. Similarly, Gosal et al. [122] attempted to use comparative analyses of three approaches (structured survey, participatory GIS, and GPS tracking) for valuation of cultural functions in New Forest National Park in the UK to evaluate the aesthetic appeal of different habitats, including agricultural landscapes. Using distance-based assessment, Vlami et al. [115] identified cultural landscapes in protected areas in Greece, scoring and analysing twelve cultural attributes to evaluate cultural values. They claim that even in data-poor regions, this assessment method of cultural attributes in protected areas could be widely applicable.

Many of the methods applied to assessing social and cultural functions have been primarily qualitative. For example, Schmidt et al. [128] used two interactive visualisation methods for rating and weighting to evaluate selected social and cultural functions based on a common classification of ESS [230] of Pentland Hills Regional Park, Scotland, exploring their impacts on land-use preferences from visitors' perspectives. Włodarczyk-Marciniak et al. [134] conducted face-to-face interviews with 540 farmers from Central Poland, investigating the social and cultural values of the local agricultural landscape. They noted that due to the impact of the CAP, globalisation and liberalisation of markets, the leisure and recreational functions of agriculture were often neglected by farmers, so that this function was underestimated in results. Partly in response to such criticism, Bonenberg [119] illustrated the importance of cultural heritage and its valuation in rural areas and proposed a multi-criteria comparative assessment method encompassing historical, aesthetic, scientific and social significance for rural areas in Poland. Yang et al. [135] similarly used interviews combined with principal components analysis and confirmatory factor analysis to assess various agricultural functions, suggesting that for both urban and rural residents in China, cultural values were vital.

Information utilised in assessing social and cultural values are often supplied by farmers or other key rural stakeholders. For example, Plieninger et al. [126] used GIS-based techniques and structured interviews with 93 individuals in Eastern Germany to assess different cultural services including aesthetic, social relations, and educational values at multiple sites. They showed that respondents from a range of socio-demographic backgrounds associated closely with cultural services at different local sites, thus analysing social valuation at a community scale. 
In addition to research in developed countries, several recent studies focus on developing countries. Bachi et al. [142] used a photo-questionnaire and a spatial multi-criteria analysis in Monta Verde, south-eastern Brazil, to assess and map non-material functions, which they disaggregated into aesthetics, recreation, cultural heritage, and inspiration. They revealed that recreational landscape users preferred a variety of different types of land cover within a rural landscape. In China, researchers have focused on the evaluation of non-market values via a monetisation approach. For example, Chen et al. [118] used a monetisation quantification method involving decomposition sums, shadow prices and cost substitution in Liulin County, Shanxi Province. They divided the social functions of cultivated land into social security (basic living security, old-age security and unemployment protection) and social stability (food security, curbing the loss of agricultural labour), observing that the social security values were generally underestimated.

Many researchers have used a combination of qualitative and quantitative methods in socio-cultural valuations. While some researchers, such as Chen et al. [118] discussed above, have preferred to employ only quantitative models to describe social and cultural functions, it appears difficult to fully describe the complex cultural functions of MFA without introducing some qualitative material. For example, measuring cultural functions in the peri-urban fringe of Hangzhou, Zhejiang province in eastern China, with the Maxent model, He et al. [117] used what they termed 'agricultural big data', namely geotagged photos acquired from social networks (e.g., Flickr) (see also [231,232]) and data on frequency of visitors to key points of interest (from digital mobile maps). They found that natural variables played the overriding aesthetic roles, but farmland with high contiguity and regularity at elevations below $200 \mathrm{~m}$ provided attractive scenery. Farmland that attracted recreationists was dependent on good infrastructure and the presence of on-farm activities. In a similar vein, Oteros-Rozas et al. [143] developed a method of displaying geo-tagged photos on social networks and evaluating the cultural functions of agriculture in five European countries based on feedback from netizens (habitual internet users), observing that the diversity of landscapes and multiple cultural functions were positively correlated.

Some scholars have studied the social and cultural functions of agriculture based on the SolVES model. This can be used to assess, map, and quantify social values such as aesthetics, landscape appreciation, and recreation by deriving social-value maps rendered as a value index, e.g., from a combination of spatial and nonspatial responses to public value and preference surveys [233]. The model has often been used in combination with maximum entropy (MaxEnt) modelling software to generate social-value maps [234], and to offer statistical models describing the relationship between the value index and other variables. For example, Bogdan et al. [137], Semmens et al. [139] and Sherrouse et al. [140] used SolVES to assess cultural ESS, Qin et al. [138] to assess conservation priorities, and Wang et al. [141] to analyse social ESS. Once again, although there are many common methods used in evaluating the social and cultural functions of MFA, a unified method of evaluation is still lacking, which has led to a low comparability of research results.

One possibility is that greater comparability might be generated using new technologies. In recent years new tools and techniques in geomatics have made it easier to provide spatial representation "of the complex interactions between all the relevant variables, in order to understand the landscape changes, the active change dynamics and their main driving forces" ([235], p. 4) [236]. For example, Loures et al. [237] indicate that there are both direct and indirect methods with which to perform aesthetic and economic evaluations of a landscape. For historic agricultural landscapes, such as those in Europe's Mediterranean countries, the framework suggested by Wood and Handley [238] is an appropriate means of categorisation for determining strategic options in landscape planning and management [239]. Their prime focus was on landscape enhancement potential with respect to four dimensions: character, condition, obsolescence, and dysfunction to determine the focus of future plans ([235], p. 16).

Lanucara et al. [240] champion the role of data sharing via the internet to enhance the application of participatory planning processes for landscape characterisation and monitoring, e.g., using spatial 
data infrastructures (SDI) and Open Geospatial Consortium (OGC) standards. However, data harmonisation is problematic via OGC, which hinders comparisons when searching and analysing data from different sources, though guidelines have been established by the European Commission (Directive 2007/2/EC). Data are typically available at a large scale and can include satellite remotely sensed imagery and various opensource data layers, such as land cover. Della Spina [241] combined public participation techniques with integrated assessment techniques to develop future planning strategies in the Tyrrhenian cultural landscape of southern Italy covering 43 municipalities. Various stakeholders were identified who input subjective views via in-depth interviews, which were combined with qualitative and quantitative indicators, cognitive maps, and multi-criteria analysis. This enabled scenario alternatives to be established to feed into the planning process for sustainable multifunctional landscape development [242].

\subsubsection{Holistic Valuations}

In terms of assessments of MFA, the focus of studies has gradually shifted from the single valuation of economic, biophysical, or cultural functions to the measurement of combined holistic functions [219]. This acknowledges that single function assessment cannot reflect the full nature and impacts of MFA [243]. Often based partly on the quantitative evaluation of multiple single functions of agriculture, the holistic valuation approach can integrate results based on the analysis of multiple single functions. The most common approach for holistic evaluation is use of an analytic hierarchy process (AHP) (a technique for decision-making in complex environments), usually combined with an indicator-based approach [225]. For example, Johansen et al. [146] used this method, including 25 indices to demonstrate MFA in a pilot project in Denmark. This showed the potential for sustainable rural development from five different perspectives (farm economics, outdoor recreation, biodiversity conservation, rural community development and environmental protection). In another example, Rovai and Andreoli [147] proposed an AHP-GIS model to evaluate productive, protective, and cultural and social services provided by agriculture in four case studies in Italy, in which weights were provided by a participatory approach. They argued that the use of this method did not require complex mathematical models and made it easier for the non-professional to understand because of its spatially interactive features.

The indicators utilised in these holistic assessments can vary widely between studies. For example, Stürck and Verburg [39] tested multifunctionality indicators at different scales in the EU, employing twelve ESS and biodiversity indicators. They found that the choice of indicator and scale of analysis strongly determined interpretation of landscape multifunctionality. At the landscape level, they could not confirm links between land use diversity and multifunctionality, but at the EU scale, multifunctionality increased in their various future scenarios. On the other hand, agricultural intensification and peri-urban growth posed large threats to the retention or development of multifunctional landscapes.

Most research on holistic MFA evaluation works at a large landscape scale, with only a few studies focusing on the micro scale (e.g., individual farms). However, the farm level may be regarded as an appropriate 'on the ground' way to analyse MFA [10]. This has been recognised in some studies looking at both landscape and farm level. For example, Fleskens et al. [156] divided MFA into five groups of functions including ecological, productive, economic, social and cultural functions at both regional level and farm level, selecting indicators to evaluate MFA in olive growing areas on the mountain slopes of north-eastern Portugal. They showed that the value of ecological functions provided by agriculture was low, though agriculture had made great contributions to the local economy, created employment opportunities, and played a role in maintaining the cultural landscape and its characteristics.

Focusing on farm-based decision making, Song et al. [151] employed a combination of qualitative methods (e.g., field surveys, interviews with stakeholders) and quantitative methods (e.g., cost substitution) to evaluate functions such as environmental health, atmospheric regulation, climate regulation, leisure and tourism, and the agricultural production function, in a sample village in the 
hinterland of Xi'an, north-west China. This showed that production remained the most important agricultural function, though grain had been replaced by high-value horticulture, while the importance of leisure and tourism had grown considerably in recent years.

Another example from China, but at a larger scale, is work by Zhang et al. [162] who used an evaluation index system for farmland to assess MFA's economic, social and ecological functions in the Huang-Huai-Hai plain, taking counties as the basic analytic unit. Liu et al. [243] also constructed a functional evaluation index system and associated analytic model to grade food production, social security, ecological conservation and comprehensive functions in the economic region surrounding Beijing and Tianjin from 1990 and 2008, showing the holistic values of multifunctionality had been strengthened, with improvements in both economic development and social security. This outcome is consistent with current policy initiatives in China, which are promoting the spread of MFA to raise rural incomes while also maintaining biodiversity and cultural heritage.

Most of the studies discussed above have dealt with landscapes dominated by agriculture. However, research has also dealt with areas where agriculture and urban development interact, such as in the peri-urban fringe or within the outer suburbs of cities $[109,244]$. Such studies can be particularly valuable where rapid industrialisation is consuming agricultural land or restricting ecological functions-a trend recorded in many parts of the world [199,245,246]. A good example is the work of $\mathrm{Gu}$ et al. [145], who used an AHP combined with weightings from 18 experienced experts to measure multifunctionality for five functions (ecological safety and ecosystem services, landscape ecology, industry development and income, infrastructure and public services, and accessibility and rural tourism) in 160 villages on the fringes of Shanghai, showing a high degree of functional variability across their study area.

Another popular and common method to holistically assess MFA is an environmental economics approach, which involves using monetisation to evaluate various functions provided by agriculture. Li et al. [163], drawing on methods from resource economics (e.g., market value, alternative costs), discussed the various values of functions of cultivated land in Qingdao, China. Their study reconstructed the cultivated land value system and evaluated various service function values of cultivated land. They used the added value of crop farming to replace the economic production value of cultivated land, evaluating the ecological value via calculations of carbon tax, afforestation costs and market prices, and for the social value by using government subsidies on social security. The results revealed that the social value was roughly equal to the sum of the combined economic and ecological values. Many researchers in China have also been working to evaluate and simulate the non-agricultural values of cultivated land resources at a large scale (e.g., provincial, municipal) to assess significant social values, but when expropriation of cultivated land for urban development occurs, the compensation provided by government is often relatively low, neglecting a range of higher alternative values [247-249].

Qualitative methods have also featured in some holistic approaches. For example, Shipley et al. [150] used Delphi and focus group methods to organise stakeholders to identify and evaluate various agricultural service functions in the Kaskaskia River Watershed, Illinois. This qualitative interactive method enabled them to generate a typology of agricultural services, including various cultural services. Fagerholm et al. [224] recognised and assessed agricultural ESS in 13 multifunctional (deep rural to peri-urban) landscapes across ten countries in Europe with deliberative and public participation GIS methods (PPGIS). Comparable with Shipley et al.'s study, they found that cultural services including outdoor recreation, aesthetic values and social interactions had received wide recognition as these were the key ESS benefits at local scales. Settlement areas were benefit 'hotspots' but many values were attributed to forest, water and mosaic landscapes. Some benefits (e.g., culture and heritage values) were spatially clustered, while many others (e.g., aesthetic values) were dispersed. This research also enabled well-being to be linked to landscape values, with five distinct clusters: access to services; tranquillity and social capital; health and nature; cultural landscapes; and place attachment. Each cluster was related to specific study sites and explained by certain social-ecological properties [250]. 
Additional work by Fagerholm et al. $[166,251]$ in Africa combined PPGIS with interviews, producing similar results. For an additional overview of the use of PPGIS in conjunction with assessment of the place-based perception of landscape values in Europe, see the survey by García-Martín [252].

Because different researchers have used different classification systems based on a variety of conceptual understandings of MFA, not to mention regional geographical differentiation, a complete and universally unified holistic evaluation of MFA has not been developed, even via the widespread use of common methods such as AHP or environmental economics approaches. While the AHP method has been widely used in evaluating the comprehensive values of MFA, because the weighting of indicators is subject to human influence (e.g., differing research perspectives and objectives of different researchers), the data and evaluation of results remain highly variable.

\subsection{Relational Values}

Multifunctional agricultural landscapes make essential contributions to rural life and nature, though their complexity can make maintenance and promotion difficult, involving various agents, knowledge, and engagement with different types of farming [253]. There is growing recognition that using traditional intrinsic or instrumental values cannot ensure the retention or production of multifunctional landscapes that fully recognise the social-ecological relationships between people and landscapes. In other words, how people connect with nature for their sustenance and wellbeing needs to be considered in the generation of multifunctional landscapes [250]. To achieve that goal, better understanding of the relational values between stakeholders and landscapes needs to be generated.

Traditionally, biodiversity conservation, environmental and cultural values of landscapes have been examined via intrinsic or instrumental perspectives [254]. The intrinsic perspective often aims to minimise human interventions and uses standardised policy tools to generate desirable environmental stewardship outcomes $[255,256]$. However, this can ignore the complexity of human values and actions, along with the potential for negative impacts of constrained or inappropriate environmental governance [257]. Advocates for an instrumental approach argue that using market-based mechanisms such as taxes, subsidies and direct payments can positively shape human behaviours [258,259]. Those tools can generate important economic signals to help facilitate farmers' engagement in environmental stewardship, but there are factors underpinning human decision making that can prejudice pro-environmental behaviour, such as farmers' knowledge, identity and attitudes to production systems and the environment $[253,254]$. Additionally, the intangible nature of cultural values embodied in agricultural landscapes makes appropriate instrumental tools difficult to apply, which in turn can compromise governance goals [260]. Therefore, in order to develop support mechanisms for multifunctional agricultural landscapes, it is important to identify the relational values of all stakeholders and understand how those values alter land management outcomes [261].

Relational values are conceived as 'preferences, principles, and virtues associated with relationships, both interpersonal and as articulated by policies and social norms' ([262], p. 1462). Currently, relational values are applied within formal policy settings to ensure environmental and cultural heritage protection as analysed across the disciplines of anthropology, biology, geography, and psychology $[260,263]$. For example, if farmers claim that they are connected closely with nature, or possess positive attitudes towards conservation, they may be more likely to take practical pro-environmental actions [264,265]. Another example is landholders' active participation in river management, which not only promotes relationships between people and their rivers, but also helps to optimise environmental outcomes [266]. These are just two examples indicating the range of potential positive contributions to multifunctional agriculture from an improved knowledge of the interactions between farmers' relational values and their connections with landscapes.

\section{Conclusions}

There are a wide range of different research concepts, frameworks and fields addressing MFA. In recent years, four dominant measurement approaches have increased the understanding of MFA 
and the varied contributions of agriculture's multiple functions to rural development and sustainability. However, as illustrated throughout this review, the concepts of MFA recognised and measured by researchers, institutions and governments are varied and often unclear. Due to reasons such as different disciplinary applications; the range of developmental backgrounds; specific or complex research purposes; the diverse range of study areas; and the different academic foci of individuals undertaking the research, opportunities for comparing or highlighting results are often limited. Further consensus is required to facilitate norms of research and data that will support arguments to stand up against commonly represented economic measures of the financial benefits of agricultural production. It may only be through such data clarity that governments who wish to recognise and invest in MFA will be able to form or shape policy that protects or enhances the multiple values of agriculture.

Nevertheless, some preliminary conclusions emerge from our review. First, few attempts have been made to make direct comparisons between different countries subject to similar or contrasting policy initiatives. Such comparative work also needs to extend to countries where MFA is occurring organically without direct material support from targeted policies, including developing countries [267,268]. Policy-related research is also required to examine the extent to which policies promoting specific agricultural functions deliver benefits to different stakeholders, including how policy can best integrate advantages conferred by natural and social resources in an area to develop different functions. In addition, more research could consider trade-offs between different functions and how these can be measured [30]. The roles of the various stakeholders and their contributions to the multiple functions of agriculture also merit further investigation, emphasising both actors at the micro-scale (e.g., individual farmers) and those who work across large scales (e.g., resource management groups, regional development agencies) [269]. The issue of scale is central to the measurement of multifunctionality, which merits both more theoretical consideration and empirical case studies. Finally, research is needed on the extent to which it is possible to develop a more unified method for evaluation of MFA, perhaps combining different methods and models to better understand the development of MFA in different contexts.

It is also important to consider just how MFA contributes to sustainable development. If the economic, environmental, and socio-cultural dimensions of MFA are in accord, opportunities will be generated for each function to reinforce the others to advance sustainable agriculture and rural development. This is essentially what Leakey and Prabhu [268] propose in terms of specific measures to enhance sustainable intensification of African farming systems. They see multi-cropping systems as the basis for enhancing sustainability but only when allied to energy security, the creation of new local business and employment opportunities off-farm, and diversification of farming systems. Similar ideals are espoused by Bretagnolle et al. [11], who champion innovative landscape scale farming systems in France that can account for changing economic and environmental targets, but which maintain economic performance and preserve natural resources. Different combinations and components may be postulated in other contexts, but with the caveat that over-reliance on any one function may not yield positive outcomes or feedbacks in the others, with the result that sustainability is not enhanced or may even be compromised, e.g., in China, increased farm-based tourism may draw both capital and labour away from agriculture, thereby adversely affecting food production and possibly the agri-ecology. Therefore, while farm household incomes may rise, this could be at the expense of broader considerations of sustainable development.

There are also global concerns that may impinge on the future promotion of MFA by potentially influencing preferences for one agricultural function at the expense of others. The most obvious of these is the growing emphasis on food security and the over-riding need for governments to ensure adequate food supplies to citizens $[270,271]$. While this is a longstanding issue, the continuing growth of the world's population towards nine billion and the increased pressure of population on resources drives demands for agriculture to increase production. This may signal moves away from MFA in favour of neo- or super-productivist modes of production as already seen in some European, North American and Australasian farming landscapes via the growth of 'industrial' agriculture and the 
adoption of new technologies to enhance production [22,272]. This gives rise to the notions of 'weak' multifunctionality in industrialised agriculture as opposed to 'strong' multifunctionality associated with farm diversification and landscapes where socio-cultural and biophysical functions are valued alongside the economic and production functions of agriculture [273]. Agricultural production could be threatened by climate change, which may also prompt the adoption of policies that favour production over multifunctionality [274]. Alternatively, growing concerns over the need to reduce environmental harm associated with industrial farming and to maintain both ecological and cultural diversity may see further adoption of policies promoting MFA. Either way, the need for more consistency in how MFA is assessed and measured is vital if associated policies are to deliver benefits across all the functions of agriculture.

Author Contributions: B.S. Conceptualization; Writing (original and revised draft preparation-review and analysis of literature); Response to reviewers; G.M.R. Conceptualization; Writing (original and revised draft preparation-context and background); Supervision; Response to reviewers; D.K.B. Writing (original draft preparation-refining and structuring); Supervision; Response to reviewers. All authors have read and agreed to the published version of the manuscript.

Funding: This research received no external funding.

Acknowledgments: The first author wishes to thank the University of Adelaide for the award of an Adelaide Scholarship International.

Conflicts of Interest: There are no conflict of interest.

\section{References}

1. Isachenko, A.G. On the method of applied landscape research. Sov. Geogr. 1973, 14, 229-243. [CrossRef]

2. Kostrowicki, J. Rural areas as multifunctional space: Some research and planning problems. In Rural Development in Highlands and High-Latitude Zones: Proceedings of A Symposium Held by The International Geographical Union's Commission on Rural Development; University of Oulu: Oulu, Finland, 1978; p. 175.

3. Manten, A.A. Fifty years of rural landscape planning in The Netherlands. Landsc. Plan. 1975, 2, $197-217$. [CrossRef]

4. Smith, P.C.; Raitz, K.B. Negro hamlets and agricultural estates in Kentucky's inner bluegrass. Geogr. Rev. 1974, 64, 217-234. [CrossRef]

5. Carter, I. The Highlands of Scotland as an underdeveloped region. In Sociology and Development; de Kadt, E., Williams, G., Eds.; Routledge: Abingdon, UK, 1974; pp. 279-311.

6. Chevalier, F. Land and Society in Colonial Mexico: The Great Hacienda; University of California Press: Berkeley, CA, USA, 1963.

7. Martins, S.W.; Wade, S.M. A Great Estate at Work: The Holkham Estate and Its Inhabitants in the Nineteenth Century; Cambridge University Press: Cambridge, UK, 1980.

8. Fielke, S.J. Multifunctional agricultural transition: Essential for local diversity in a globalised world. In Handbook on the Globalisation of Agriculture; Robinson, G.M., Carson, D.A., Eds.; Edward Elgar Publishing: Cheltenham, UK; Northampton, MA, USA, 2015.

9. Madureira, L.; Susete, C. Multifunctional agriculture as an innovation path for rural areas. Econ. Agric. 2018, $57,121-132$.

10. Wilson, G.A. Multifunctional Agriculture: A Transition Theory Perspective; CABI: Wallingford, UK; Cambridge, MA, USA, 2007.

11. Bretagnolle, V.; Berthet, E.; Gross, N.; Gauffre, B.; Plumejeaud, C.; Houte, S.; Badenhausser, I.; Monceau, K.; Allier, F.; Monestiez, P.; et al. Towards sustainable and multifunctional agriculture in farmland landscapes: Lessons from the integrative approach of a French LTSER platform. Sci. Total Environ. 2018, 627, 822-834. [CrossRef]

12. Granvik, M.; Lindberg, G.; Stigzelius, K.A.; Fahlbeck, E.; Surry, Y. Prospects of multifunctional agriculture as a facilitator of sustainable rural development: Swedish experience of Pillar 2 of the Common Agricultural Policy (CAP). Nor. Geogr. Tidsskr. 2012, 66, 155-166. [CrossRef]

13. Leakey, R.R.B. Multifunctional Agriculture: Achieving Sustainable Development in Africa; Academic Press: London, UK, 2017. 
14. Spataru, A.; Faggian, R.; Docking, A. Principles of multifunctional agriculture for supporting agriculture in metropolitan peri-urban areas: The case of Greater Melbourne, Australia. J. Rural Stud. 2020, 74, 34-44. [CrossRef]

15. Commission of the European Communities (CEC). The Future of Rural Society; CEC: Brussels, Belgium, 1988.

16. Belletti, G.; Brunori, G.; Marescotti, A.; Rossi, A. Multifunctionality and rural development: A multilevel approach. In Multifunctional Agriculture: A New Paradigm for European Agriculture and Rural Development; van Huylenbroeck, G., Durand, G., Eds.; Ashgate: Farnham, UK, 2003; pp. 55-80.

17. Committee of Agricultural Organisations in the European Union (CAOEU). The European Model of Agriculture: The Way ahead; Committee of Agricultural Organizations in the European Union: Brussels, Belgium, 1999.

18. Organisation for Economic Co-operation and Development (OECD). Multifunctionality: Towards and Analytical Framework; Organisation for Economic Co-operation and Development: Paris, France, 2001.

19. Randall, A. Valuing the outputs of multifunctional agriculture. Eur. Rev. Agric. Econ. 2002, 29, $289-307$. [CrossRef]

20. Swaffield, S.R.; Corry, R.C.; Opdam, P.; McWilliam, W.; Primdahl, J. Connecting business with the agricultural landscape: Business strategies for sustainable rural development. Bus. Strategy Environ. 2019, 28, 1357-1369. [CrossRef]

21. Brummel, R.F.; Nelson, K.C. Does multifunctionality matter to US farmers? Farmer motivations and conceptions of multifunctionality in dairy systems. J. Environ. Manag. 2014, 146, 451-462. [CrossRef]

22. Pelucha, M.; Kveton, V. The role of EU rural development policy in the neo-productivist agricultural paradigm. Reg. Stud. 2017, 51, 1860-1870. [CrossRef]

23. Raymond, C.M.; Reed, M.S.; Bieling, C.; Robinson, G.M.; Plieninger, T. Integrating different understandings of landscape stewardship into the design of agri-environmental schemes. Environ. Conserv. 2016, 43, 350-358. [CrossRef]

24. Kawai, M.; Lee, J.W. Beyond the crisis: Toward balanced and sustainable growth. In Rebalancing for Sustainable Growth; Kawai, M., Lee, J.-W., Eds.; Springer: Tokyo, Japan, 2015; pp. 251-260.

25. Fielke, S.J.; Bardsley, D.K. Regional agricultural governance in peri-urban and rural South Australia: Strategies to improve multifunctionality. Sustain. Sci. 2015, 10, 231-243. [CrossRef]

26. Fielke, S.J.; Bardsley, D.K. South Australian farmers' markets: Tools for enhancing the multifunctionality of Australian agriculture. GeoJournal 2013, 78, 759-776. [CrossRef]

27. Parrott, L.; Kyle, C.; Hayot-Sasson, V.; Bouchard, C.; Cardille, J.A. Planning for ecological connectivity across scales of governance in a multifunctional regional landscape. Ecosyst. People 2019, 15, 204-213. [CrossRef]

28. Rallings, A.M.; Smukler, S.M.; Gergel, S.E.; Mullinix, K. Towards multifunctional land use in an agricultural landscape: A trade-off and synergy analysis in the Lower Fraser Valley, Canada. Landsc. Urban Plan. 2019, 184, 88-100. [CrossRef]

29. Liu, Y. Research on the urban-rural integration and rural revitalization in the new era in China. Acta Geogr. Sin. 2018, 73, 637-650.

30. Zhao, X.; Sun, H.; Chen, B.; Xia, X.; Li, P. China's rural human settlements: Qualitative evaluation, quantitative analysis and policy implications. Ecol. Indic. 2019, 105, 398-405. [CrossRef]

31. Marsden, T.; Sonnino, R. Rural development and the regional state: Denying multifunctional agriculture in the UK. J. Rural Stud. 2008, 24, 422-431. [CrossRef]

32. Bardsley, D.K. Risk alleviation via in situ agrobiodiversity conservation: Drawing from experiences in Switzerland, Turkey and Nepal. Agric. Ecosyst. Environ. 2003, 99, 149-157. [CrossRef]

33. Maye, D.; Ilbery, B.; Watts, D. Farm diversification, tenancy and CAP reform: Results from a survey of tenant farmers in England. J. Rural Stud. 2009, 25, 333-342. [CrossRef]

34. Van der Ploeg, J.D.; Long, A.; Banks, J. Rural development: The state of the art. In Living Countrysides: Rural Development Processes in Europe: The State of the Art; Van der Ploeg, J.D., Long, A., Banks, J., Eds.; Elsevier: Doetinchem, The Netherlands, 2002; pp. 8-17.

35. Van der Ploeg, J.D.; Renting, H.; Brunori, G.; Knickel, K.; Mannion, J.; Marsden, T.; de Roest, K.; Sevilla-Guzmán, E.; Ventura, F. Rural development: From practices and policies towards theory. Sociol. Rural. 2000, 40, 391-408. [CrossRef] 
36. Pinto-Correia, T.; Primdahl, J. When rural landscapes change functionality: Constraints and development options for multifunctional landscapes. Examples from contrasting case-studies in Portugal and Denmark. In Multifunctional Rural Land Management: Economics and Policies; Brouwer, F., van der Heide, C.M., Eds.; Earthscan: London, UK, 2009; pp. 213-234.

37. Galler, C.; von Haaren, C.; Albert, C. Optimizing environmental measures for landscape multi-functionality: Effectiveness, efficiency and recommendations for agri-environmental programs. J. Environ. Manag. 2015, 151, 243-257. [CrossRef] [PubMed]

38. Peng, J.; Liu, Y.; Liu, Z.; Yang, Y. Mapping spatial non-stationarity of human-natural factors associated with agricultural landscape multifunctionality in Beijing-Tianjin-Hebei region, China. Agric. Ecosyst. Environ. 2017, 246, 221-233. [CrossRef]

39. Stürck, J.; Verburg, P.H. Multifunctionality at what scale? A landscape multifunctionality assessment for the European Union under conditions of land use change. Landsc. Ecol. 2017, 32, 481-500. [CrossRef]

40. Bardsley, D.K.; Thomas, I. Valuing local wheat landraces for agrobiodiversity conservation in Northeast Turkey. Agric. Ecosyst. Environ. 2005, 106, 407-412. [CrossRef]

41. Clark, S. Financial viability of an on-farm processing and retail enterprise: A case study of value-added agriculture in rural Kentucky (USA). Sustainability 2020, 12, 708. [CrossRef]

42. Johnson, T.G. The role of agriculture and farm household diversification in the US rural economy. In Rural Policies and Employment: Transatlantic Experiences; Davidova, S.M., Thomson, K.J., Mishra, A.K., Eds.; World Scientific Publishing Europe: London, UK, 2019; pp. 315-330.

43. Renting, H.; Rossing, W.A.H.; Groot, J.C.J.; Van der Ploeg, J.D.; Laurent, C.; Perraud, D.; Van Ittersum, M.K. Exploring multifunctional agriculture. A review of conceptual approaches and prospects for an integrative transitional framework. J. Environ. Manag. 2009, 90, S112-S123. [CrossRef]

44. Stojferahn, C.W. The condition of rural sustainability, by Terry Marsden. Rural Sociol. 2004, 69, 313-316. [CrossRef]

45. Peng, J.; Hu, X.; Qiu, S.; Meersmans, J.; Liu, Y. Multifunctional landscapes identification and associated development zoning in mountainous area. Sci. Total Environ. 2019, 660, 765-775. [CrossRef]

46. Ehrlich, P.R.; Kremen, C.; Ehrlich, A.H. Human impacts on ecosystems: An overview. In Encyclopedia of Biodiversity, 2nd ed.; Levin, S.A., Ed.; Academic Press: Cambridge, MA, USA, 2013; pp. 153-161.

47. Meerburg, B.G.; Korevaar, H.; Haubenhofer, D.K.; Blom-Zandstra, M.; Van Keulen, H. The changing role of agriculture in Dutch society. J. Agric. Sci. 2009, 147, 511-521. [CrossRef]

48. Holmes, J. Impulses towards a multifunctional transition in rural Australia: Gaps in the research agenda. J. Rural Stud. 2006, 22, 142-160. [CrossRef]

49. Hölting, L.; Beckmann, M.; Volk, M.; Cord, A.F. Multifunctionality assessments-More than assessing multiple ecosystem functions and services? A quantitative literature review. Ecol. Indic. 2019, 103, 226-235. [CrossRef]

50. De Groot, R.S.; Alkemade, R.; Braat, L.; Hein, L.; Willemen, L. Challenges in integrating the concept of ecosystem services and values in landscape planning, management and decision making. Ecol. Complex. 2010, 7, 260-272. [CrossRef]

51. Burkhard, B.; Kroll, F.; Müller, F.; Windhorst, W. Landscapes' capacities to provide ecosystem services-A concept for land-cover based assessments. Landsc. Online 2009, 15, 1-22. [CrossRef]

52. Randall, A.; Kidder, A.; Chen, D.R. Meta-Analysis for Benefits Transfer-Toward Value Estimates for Some Outputs of Multifunctional Agriculture (No. 725-2016-49345). In Proceedings of the International Congress, Ghent, Belgium, 26-29 August 2008.

53. Randall, A. A consistent valuation and pricing framework for non-commodity outputs: Progress and prospects. Agric. Ecosyst. Environ. 2007, 120, 21-30. [CrossRef]

54. Yrjölä, T.; Kola, J. Multifunctional agriculture: Cost-benefit approach. Agric. Econ. Res. Inst. Res. Rep. 2000, 241, 39-57.

55. Sal, A.G.; García, A.G. A comprehensive assessment of multifunctional agricultural land-use systems in Spain using a multi-dimensional evaluative model. Agric. Ecosyst. Environ. 2007, 120, 82-91.

56. Madureira, L.; Rambonilaza, T.; Karpinski, I. Review of methods and evidence for economic valuation of agricultural non-commodity outputs and suggestions to facilitate its application to broader decisional contexts. Agric. Ecosyst. Environ. 2007, 120, 5-20. [CrossRef] 
57. Ahtiainen, H.; Pouta, E.; Liski, E.; Myyrä, S.; Assmuth, A. Importance of economic, social, and environmental objectives of agriculture for stakeholders-A meta-analysis. Agroecol. Sustain. Food Syst. 2015, 39, 1047-1068. [CrossRef]

58. El Bilali, $\mathrm{H}$. The multi-level perspective in research on sustainability transitions in agriculture and food systems: A systematic review. Agriculture 2019, 9, 74. [CrossRef]

59. Huber, R.; Finger, R. A meta-analysis of the Willingness to Pay for cultural services from grasslands in Europe. J. Agric. Econ. 2019, 71, 357-383. [CrossRef]

60. Lee, H.; Lautenbach, S.; Nieto, A.P.G.; Bondeau, A.; Cramer, W.; Geijzendorffer, I.R. The impact of conservation farming practices on Mediterranean agro-ecosystem services provisioning-A meta-analysis. Reg. Environ. Chang. 2019, 19, 2187-2202. [CrossRef]

61. Van Zanten, B.T.; Verburg, P.H.; Espinosa, M.; Gomez-y-Paloma, S.; Galimberti, G.; Kantelhardt, J.; Kapfer, M.; Lefebvre, M.; Manrique, R.; Piorr, A.; et al. European agricultural landscapes, common agricultural policy and ecosystem services: A review. Agron. Sustain. Dev. 2014, 34, 309-325. [CrossRef]

62. Wiggering, H.; Weißhuhn, P.; Burkhard, B. Agrosystem services: An additional terminology to better understand ecosystem services delivered by agriculture. Landsc. Online 2016, 49, 1-15. [CrossRef]

63. García-Martín, M.; Bieling, C.; Hart, A.; Plieninger, T. Integrated landscape initiatives in Europe: Multi-sector collaboration in multi-functional landscapes. Land Use Policy 2016, 58, 43-53. [CrossRef]

64. van Vliet, J.; de Groot, H.L.; Rietveld, P.; Verburg, P.H. Manifestations and underlying drivers of agricultural land use change in Europe. Landsc. Urban Plan. 2015, 133, 24-36. [CrossRef]

65. Kizos, T.; Plieninger, T.; Bieling, C.; Martín-Rubí, M.G.; Balatsos, T.; Hart, A.K.; Draux, H.; Fagerholm, N.; Bürgi, M.; Kuemmerle, T.; et al. HERCULES Project-D1. 3: Report on the Three Individual Systematic Reviews (Rates and Patterns, Drivers and Outcomes, Actors) 2016. Available online: http://www.herculeslandscapes.eu/tartalom/HERCULES_WP1_D1_3.pdf (accessed on 1 July 2020).

66. Plieninger, T.; Bieling, C.; Fagerholm, N.; Byg, A.; Hartel, T.; Hurley, P.; López-Santiago, C.A.; Nagabhatla, N.; Oteros-Rozas, E.; Raymond, C.M.; et al. The role of cultural ecosystem services in landscape management and planning. Curr. Opin. Environ. Sustain. 2015, 14, 28-33. [CrossRef]

67. Alcon, F.; Marín-Miñano, C.; Zabala, J.A.; de-Miguel, M.D.; Martínez-Paz, J.M. Valuing diversification benefits through intercropping in Mediterranean agroecosystems: A choice experiment approach. Ecol. Econ. 2020, 171, 106593. [CrossRef]

68. Bernués, A.; Rodríguez-Ortega, T.; Alfnes, F.; Clemetsen, M.; Eik, L.O. Quantifying the multifunctionality of fjord and mountain agriculture by means of sociocultural and economic valuation of ecosystem services. Land Use Policy 2015, 48, 170-178. [CrossRef]

69. Chen, B.; Qiu, Z.; Usio, N.; Nakamura, K. Conservation and contingent valuation of farming landscape amenities by visitors: A case study of terraced paddy fields in Central Japan. Paddy Water Environ. 2018, 16, 561-570. [CrossRef]

70. Dupras, J.; Laurent-Lucchetti, J.; Revéret, J.P.; DaSilva, L. Using contingent valuation and choice experiment to value the impacts of agri-environmental practices on landscapes aesthetics. Landsc. Res. 2018, 43, 679-695. [CrossRef]

71. Jung, H. Estimating the social value of multifunctional agriculture (MFA) with choice experiment. Agric. Econ. 2020, 66, 120-128. [CrossRef]

72. Kubíčková, S. Support of the landscape amenity function of agriculture and trade liberalisation. Acta Univ. Agric. Et Silvic. Mendel. Brun. 2015, 52, 77-86. [CrossRef]

73. Mazzocchi, C.; Sali, G. Assessing the value of pastoral farming in the Alps using choice experiments: Evidence for public policies and management. J. Environ. Plan. Manag. 2019, 62, 552-567. [CrossRef]

74. Nambuge, V.; Qineti, A.; Rajcaniova, M.; Nambuge, D. Valuation of public goods in agricultural landscape: The case of Slovakia. Adv. Glob. Bus. Econ. 2018, 21. [CrossRef]

75. Novikova, A.; Rocchi, L.; Vaznonis, B. Valuing Agricultural Landscape: Lithuanian Case Study Using a Contingent Valuation Method. Sustainability 2019, 11, 2648. [CrossRef]

76. Ohe, Y. Roles of farm pluriactivity on multifunctional agriculture in a mountainous rural community. In Community-Based Rural Tourism and Entrepreneurship; Ohe, Y., Ed.; Springer: Singapore, 2020; pp. 51-73.

77. Ragkos, A.; Theodoridis, A. Valuation of environmental and social functions of the multifunctional Cypriot agriculture. Land Use Policy 2016, 54, 593-601. [CrossRef] 
78. Sangkapitux, C.; Suebpongsang, P.; Punyawadee, V.; Pimpaoud, N.; Konsurin, J.; Neef, A. Eliciting citizen preferences for multifunctional agriculture in the watershed areas of northern Thailand through choice experiment and latent class models. Land Use Policy 2017, 67, 38-47. [CrossRef]

79. Tagliafierro, C.; Boeri, M.; Longo, A.; Hutchinson, W.G. Stated preference methods and landscape ecology indicators: An example of transdisciplinarity in landscape economic valuation. Ecol. Econ. 2016, 127, 11-22. [CrossRef]

80. Torres-Miralles, M.; Grammatikopoulou, I.; Rescia, A.J. Employing contingent and inferred valuation methods to evaluate the conservation of olive groves and associated ecosystem services in Andalusia (Spain). Ecosyst. Serv. 2017, 26, 258-269. [CrossRef]

81. van Zanten, B.T.; Zasada, I.; Koetse, M.J.; Ungaro, F.; Häfner, K.; Verburg, P.H. A comparative approach to assess the contribution of landscape features to aesthetic and recreational values in agricultural landscapes. Ecosyst. Serv. 2016, 17, 87-98. [CrossRef]

82. Vivithkeyoonvong, S.; Jourdain, D. Willingness to pay for ecosystem services provided by irrigated agriculture in Northeast Thailand. Int. J. Biodivers. Sci. Ecosyst. Serv. Manag. 2017, 13, 14-26. [CrossRef]

83. Sejati, L.B.; Arifien, Y.; Maad, F. Economic valuation of rice agricultural land in Bogor regency. J. Phys. Conf. Ser. 2020, 1517, 012024. [CrossRef]

84. Zabala, J.A.; Marín-Miñano, C.; Albaladejo-García, J.A.; López-Becerra, E.I.; de Miguel, M.D.; Martínez-Paz, J.M.; Alcon, F. A valuation-based approach for irrigated agroecosystem services. In Proceedings of the 172nd EAAE Seminar, Brussels, Belgium, 28-29 May 2019.

85. Zhao, F.; Huang, M. Exploring the non-use value of an important agricultural heritage system: Case of Lingnan Litchi Cultivation System (Zengcheng) in Guangdong, China. Sustainability 2020, 12, 3638. [CrossRef]

86. Baum, R.; Kozera-Kowalska, M. Value of agricultural externalities on the example of an agritourism farm. Rocz. Ann. 2019, 2019. [CrossRef]

87. Dong, S.; Cheng, H.; Li, Y.; Li, F.; Wang, Z.; Chen, F. Rural landscape types and recreational value spatial analysis of valley area of Loess Plateau: A case of Hulu Watershed, Gansu Province, China. Chin. Geogr. Sci. 2017, 27, 286-297. [CrossRef]

88. Huang, C.H.; Wang, C.H. Estimating the total economic value of cultivated flower land in Taiwan. Sustainability 2015, 7, 4764-4782. [CrossRef]

89. Münch, A.; Nielsen, S.P.P.; Racz, V.J.; Hjalager, A.M. Towards multifunctionality of rural natural environments?-An economic valuation of the extended buffer zones along Danish rivers, streams and lakes. Land Use Policy 2016, 50, 1-16. [CrossRef]

90. Blasi, E.; Passeri, N.; Franco, S.; Galli, A. An ecological footprint approach to environmental-economic evaluation of farm results. Agric. Syst. 2016, 145, 76-82. [CrossRef]

91. Ketema, H.; Wu, W.; Temesgen, H. Quantifying the ecological values of land use types via criteria-based farmers' assessment and empirically analysed soil properties in southern Ethiopia. Appl. Ecol. Environ. Res. 2018, 16, 7713-7739. [CrossRef]

92. Yu, Z.; Qin, T.; Yan, D.; Yang, M.; Yu, H.; Shi, W. The Impact on the ecosystem services value of the ecological shelter zone reconstruction in the Upper Reaches Basin of the Yangtze River in China. Int. J. Environ. Res. Public Health 2018, 15, 2273. [CrossRef] [PubMed]

93. Aneva, I.Y.; Zhelev, P.; Topchieva, M.K. Evaluation of natural habitats in Western Balkan range and in Pazardzhik-Plovdiv region in relation to sustainable agriculture. In Book of Abstracts, First European Symposium Research, Conservation and Management of Biodiversity in The European Seashores (RCMBES); Peev, D.R., Gärtner, G., Stoyneva-Gärtner, M.P., Popova, N.P., Georgieva, E.E., Eds.; Bulgarian Academy of Sciences: Sofia, Bulgaria, 2017; p. 58.

94. Lecina-Diaz, J.; Alvarez, A.; De Cáceres, M.; Herrando, S.; Vayreda, J.; Retana, J. Are protected areas preserving ecosystem services and biodiversity? Insights from Mediterranean forests and shrublands. Landsc. Ecol. 2019, 34, 2307-2321. [CrossRef]

95. Lefcheck, J.S.; Byrnes, J.E.; Isbell, F.; Gamfeldt, L.; Griffin, J.N.; Eisenhauer, N.; Hensel, M.J.S.; Hector, A.; Cardinale, B.J.; Duffy, J.E. Biodiversity enhances ecosystem multifunctionality across trophic levels and habitats. Nat. Commun. 2015, 6, 6936. [CrossRef] 
96. Liu, Y.; Duan, M.; Zhang, X.; Zhang, X.; Yu, Z.; Axmacher, J.C. Effects of plant diversity, habitat and agricultural landscape structure on the functional diversity of carabid assemblages in the North China Plain. Insect Conserv. Divers. 2015, 8, 163-176. [CrossRef]

97. Puig-Montserrat, X.; Stefanescu, C.; Torre, I.; Palet, J.; Fàbregas, E.; Dantart, J.; Arrizabalaga, A.; Flaquer, C. Effects of organic and conventional crop management on vineyard biodiversity. Agric. Ecosyst. Environ. 2017, 243, 19-26. [CrossRef]

98. Rollin, O.; Pérez-Méndez, N.; Bretagnolle, V.; Henry, M. Preserving habitat quality at local and landscape scales increases wild bee diversity in intensive farming systems. Agric. Ecosyst. Environ. 2019, 275, 73-80. [CrossRef]

99. Bhagabati, N.K.; Ricketts, T.; Sulistyawan, T.B.S.; Conte, M.; Ennaanay, D.; Hadian, O.; McKenzie, E.; Olwero, N.; Rosenthal, A.; Tallis, H.; et al. Ecosystem services reinforce Sumatran tiger conservation in land use plans. Biol. Conserv. 2014, 169, 147-156. [CrossRef]

100. Dai, L.; Li, S.; Lewis, B.J.; Wu, J.; Yu, D.; Zhou, W.; Wu, S. The influence of land use change on the spatial-temporal variability of habitat quality between 1990 and 2010 in Northeast China. J. For. Res. 2019, 30, 2227-2236. [CrossRef]

101. Du, S.; Rong, Y. The biodiversity assessment of land use in Shanxi Province based on InVEST model. Environ. Sustain. Dev. 2015, 40, 65-70. (In Chinese)

102. Goldstein, J.H.; Caldarone, G.; Duarte, T.K.; Ennaanay, D.; Hannahs, N.; Mendoza, G.; Daily, G.C. Integrating ecosystem-service tradeoffs into land-use decisions. Proc. Natl. Acad. Sci. USA 2012, 109, 7565-7570. [CrossRef]

103. Ma, Y.; Shi, Y.; Hao, S.; Zhao, J. Evolution and prediction of land cover and biodiversity function in Loess Hilly Region. Arta Ecol. Sin. 2019, 39, 2806-2815. (In Chinese)

104. Pham, H.V.; Sperotto, A.; Torresan, S.; Acuña, V.; Jorda-Capdevila, D.; Rianna, G.; Marcomini, A.; Critto, A. Coupling scenarios of climate and land-use change with assessments of potential ecosystem services at the river basin scale. Ecosyst. Serv. 2019, 40, 101045. [CrossRef]

105. Polasky, S.; Nelson, E.; Pennington, D.; Johnson, K.A. The impact of land-use changes on ecosystem services, biodiversity and returns to landowners: A case study in the state of Minnesota. Environ. Resour. Econ. 2011, 48, 219-242. [CrossRef]

106. Belem, M.; Saqalli, M. Development of an integrated generic model for multi-scale assessment of the impacts of agro-ecosystems on major ecosystem services in West Africa. J. Environ. Manag. 2017, 202, 117-125. [CrossRef]

107. Ma, F.; Eneji, A.E.; Liu, J. Assessment of ecosystem services and dis-services of an agro-ecosystem based on extended emergy framework: A case study of Luancheng county, North China. Ecol. Eng. 2015, 82, 241-251. [CrossRef]

108. Mattsson, E.; Ostwald, M.; Nissanka, S.P.; Pushpakumara, D.K.N.G. Quantification of carbon stock and tree diversity of homegardens in a dry zone area of Moneragala district, Sri Lanka. Agrofor. Syst. 2015, 89, 435-445. [CrossRef]

109. Peng, J.; Liu, Z.; Liu, Y.; Hu, X.; Wang, A. Multifunctionality assessment of urban agriculture in Beijing City, China. Sci. Total Environ. 2015, 537, 343-351. [CrossRef]

110. Peng, J.; Chen, X.; Liu, Y.; Lü, H.; Hu, X. Spatial identification of multifunctional landscapes and associated influencing factors in the Beijing-Tianjin-Hebei region, China. Appl. Geogr. 2016, 74, 170-181. [CrossRef]

111. Tenerelli, P.; Püffel, C.; Luque, S. Spatial assessment of aesthetic services in a complex mountain region: Combining visual landscape properties with crowdsourced geographic information. Landsc. Ecol. 2017, 32, 1097-1115. [CrossRef]

112. Williams, A.T. Some scenic evaluation techniques. In Coastal Scenery: Evaluatuion and Management; Rangel-Buitraro, N., Ed.; Springer: Cham, Switzerland, 2019; pp. 43-65.

113. Rewitzer, S.; Huber, R.; Grêt-Regamey, A.; Barkmann, J. Economic valuation of cultural ecosystem service changes to a landscape in the Swiss Alps. Ecosyst. Serv. 2017, 26, 197-208. [CrossRef]

114. Bullock, C.; Joyce, D.; Collier, M. An exploration of the relationships between cultural ecosystem services, socio-cultural values and well-being. Ecosyst. Serv. 2018, 31, 142-152. [CrossRef]

115. Vlami, V.; Kokkoris, I.P.; Zogaris, S.; Cartalis, C.; Kehayias, G.; Dimopoulos, P. Cultural landscapes and attributes of "culturalness" in protected areas: An exploratory assessment in Greece. Sci. Total Environ. 2017, 595, 229-243. [CrossRef] 
116. Willemen, L.; Hein, L.; van Mensvoort, M.E.; Verburg, P.H. Space for people, plants, and livestock? Quantifying interactions among multiple landscape functions in a Dutch rural region. Ecol. Indic. 2010, 10, 62-73. [CrossRef]

117. He, S.; Su, Y.; Shahtahmassebi, A.R.; Huang, L.; Zhou, M.; Gan, M.; Deng, J.; Zhao, G.; Wang, K. Assessing and mapping cultural ecosystem services supply, demand and flow of farmlands in the Hangzhou metropolitan area, China. Sci. Total Environ. 2019, 692, 756-768. [CrossRef]

118. Chen, L.; Qu, F.; Shi, X. The social value of cultivated land resources: A case study in Liulin county of Shanxi province. Resour. Sci. 2006, 28, 86-90. (In Chinese)

119. Bonenberg, W. The role of cultural heritage in sustainable development. Values and valuation as key factors in spatial planning of rural areas. In International Conference on Applied Human Factors and Ergonomics; Springer: Cham, Switzerland, 2019; pp. 124-134.

120. Bernués, A.; Tello-García, E.; Rodríguez-Ortega, T.; Ripoll-Bosch, R.; Casasús, I. Agricultural practices, ecosystem services and sustainability in High Nature Value farmland: Unraveling the perceptions of farmers and nonfarmers. Land Use Policy 2016, 59, 130-142. [CrossRef]

121. Darvill, R.; Lindo, Z. Quantifying and mapping ecosystem service use across stakeholder groups: Implications for conservation with priorities for cultural values. Ecosyst. Serv. 2015, 13, 153-161. [CrossRef]

122. Gosal, A.S.; Newton, A.C.; Gillingham, P.K. Comparison of methods for a landscape-scale assessment of the cultural ecosystem services associated with different habitats. Int. J. Biodivers. Sci. Ecosyst. Serv. Manag. 2018, 14, 91-104. [CrossRef]

123. Hahn, T.; Heinrup, M.; Lindborg, R. Landscape heterogeneity correlates with recreational values: A case study from Swedish agricultural landscapes and implications for policy. Landsc. Res. 2018, 43, 696-707. [CrossRef]

124. Junge, X.; Schüpbach, B.; Walter, T.; Schmid, B.; Lindemann-Matthies, P. Aesthetic quality of agricultural landscape elements in different seasonal stages in Switzerland. Landsc. Urban Plan. 2015, 133, 67-77. [CrossRef]

125. Kvakkestad, V.; Rørstad, P.K.; Vatn, A. Norwegian farmers' perspectives on agriculture and agricultural payments: Between productivism and cultural landscapes. Land Use Policy 2015, 42, 83-92. [CrossRef]

126. Plieninger, T.; Dijks, S.; Oteros-Rozas, E.; Bieling, C. Assessing, mapping, and quantifying cultural ecosystem services at community level. Land Use Policy 2013, 33, 118-129. [CrossRef]

127. Plieninger, T.; Torralba, M.; Hartel, T.; Fagerholm, N. Perceived ecosystem services synergies, trade-offs, and bundles in European high nature value farming landscapes. Landsc. Ecol. 2019, 34, 1565-1581. [CrossRef]

128. Schmidt, K.; Walz, A.; Martín-López, B.; Sachse, R. Testing socio-cultural valuation methods of ecosystem services to explain land use preferences. Ecosyst. Serv. 2017, 26, 270-288. [CrossRef]

129. Schirpke, U.; Altzinger, A.; Leitinger, G.; Tasser, E. Change from agricultural to touristic use: Effects on the aesthetic value of landscapes over the last 150 years. Landsc. Urban Plan. 2019, 187, 23-35. [CrossRef]

130. Schirpke, U.; Timmermann, F.; Tappeiner, U.; Tasser, E. Cultural ecosystem services of mountain regions: Modelling the aesthetic value. Ecol. Indic. 2016, 69, 78-90. [CrossRef]

131. Soy-Massoni, E.; Langemeyer, J.; Varga, D.; Sáez, M.; Pintó, J. The importance of ecosystem services in coastal agricultural landscapes: Case study from the Costa Brava, Catalonia. Ecosyst. Serv. 2016, 17, 43-52. [CrossRef]

132. Tulla, A.F.; Vera, A.; Valldeperas, N.; Guirado, C. Social return and economic viability of social farming in Catalonia: A Case-Study Analysis. Eur. Countrys. 2018, 10, 398-428. [CrossRef]

133. Villegas-Palacio, C.; Berrouet, L.; López, C.; Ruiz, A.; Upegui, A. Lessons from the integrated valuation of ecosystem services in a developing country: Three case studies on ecological, socio-cultural and economic valuation. Ecosyst. Serv. 2016, 22, 297-308. [CrossRef]

134. Włodarczyk-Marciniak, R.; Frankiewicz, P.; Krauze, K. Socio-cultural valuation of Polish agricultural landscape components by farmers and its consequences. J. Rural Stud. 2020, 74, 190-200. [CrossRef]

135. Yang, S.; Zhao, W.; Pereira, P.; Liu, Y. Socio-cultural valuation of rural and urban perception on ecosystem services and human well-being in Yanhe watershed of China. J. Environ. Manag. 2019, 251, 109615. [CrossRef] [PubMed]

136. Zoderer, B.M.; Stanghellini, P.S.L.; Tasser, E.; Walde, J.; Wieser, H.; Tappeiner, U. Exploring socio-cultural values of ecosystem service categories in the Central Alps: The influence of socio-demographic factors and landscape type. Reg. Environ. Chang. 2016, 16, 2033-2044. [CrossRef] 
137. Bogdan, S.M.; Stupariu, I.; Andratopârceanu, A.; Nastase, I.I. Mapping social values for cultural ecosystem services in a mountain landscape in the Romanian Carpathians. Carpathian J. Earth Environ. Sci. 2019, 14, 199-208. [CrossRef]

138. Qin, K.; Li, J.; Liu, J.; Yan, L.; Huang, H. Setting conservation priorities based on ecosystem services-A case study of the Guanzhong-Tianshui Economic Region. Sci. Total Environ. 2019, 650, 3062-3074. [CrossRef]

139. Semmens, D.J.; Sherrouse, B.C.; Ancona, Z.H. Using social-context matching to improve spatial function-transfer performance for cultural ecosystem service models. Ecosyst. Serv. 2019, 38, 100945. [CrossRef]

140. Sherrouse, B.C.; Semmens, D.J.; Ancona, Z.H.; Brunner, N.M. Analyzing land-use change scenarios for trade-offs among cultural ecosystem services in the Southern Rocky Mountains. Ecosyst. Serv. 2017, 26, 431-444. [CrossRef]

141. Wang, Y.; Fu, B.; Lyu, Y.; Yang, K.; Che, Y. Assessment of the social values of ecosystem services based on SolVES model: A case study of Wusong Paotaiwan Wetland Forest Park, Shanghai, China. Chin. J. Appl. Ecol. 2016, 27, 1767-1774. (In Chinese)

142. Bachi, L.; Ribeiro, S.C.; Hermes, J.; Saadi, A. Cultural Ecosystem Services (CES) in landscapes with a tourist vocation: Mapping and modeling the physical landscape components that bring benefits to people in a mountain tourist destination in southeastern Brazil. Tour. Manag. 2020, 77, 104017. [CrossRef]

143. Oteros-Rozas, E.; Martín-López, B.; Fagerholm, N.; Bieling, C.; Plieninger, T. Using social media photos to explore the relation between cultural ecosystem services and landscape features across five European sites. Ecol. Indic. 2018, 94, 74-86. [CrossRef]

144. Carmona-Torres, C.; Parra-López, C.; Hinojosa-Rodríguez, A.; Sayadi, S. Farm-level multifunctionality associated with farming techniques in olive growing: An integrated modeling approach. Agric. Syst. 2014, 127, 97-114. [CrossRef]

145. Gu, X.; Xie, B.; Zhang, Z.; Guo, H.D. Rural multifunction in Shanghai suburbs: Evaluation and spatial characteristics based on villages. Habitat Int. 2019, 92, 102041. [CrossRef]

146. Johansen, P.H.; Ejrnæs, R.; Kronvang, B.; Olsen, J.V.; Præstholm, S.; Schou, J.S. Pursuing collective impact: A novel indicator-based approach to assessment of shared measurements when planning for multifunctional land consolidation. Land Use Policy 2018, 73, 102-114. [CrossRef]

147. Rovai, M.; Andreoli, M. Integrating AHP and GIS techniques for rural landscape and agricultural activities planning. In Multicriteria Annalysis in Agriculture; Berbel, J., Bournaris, T., Manos, B., Matsatsinis, N., Viaggi, D., Eds.; Springer: Cham, Switzerland, 2018; pp. 69-98.

148. Sajadian, M.; Khoshbakht, K.; Liaghati, H.; Veisi, H.; Damghani, A.M. Developing and quantifying indicators of organic farming using analytic hierarchy process. Ecol. Indic. 2017, 83, 103-111. [CrossRef]

149. Sousa, A.R.; Parra-López, C.; Sayadi-Gmada, S.; Barandica, J.M.; Rescia, A.J. A multifunctional assessment of integrated and ecological farming in olive agroecosystems in southwestern Spain using the Analytic Hierarchy Process. Ecol. Econ. 2020, 173, 106658. [CrossRef]

150. Shipley, N.J.; Johnson, D.N.; van Riper, C.J.; Stewart, W.P.; Chu, M.L.; Suski, C.D.; Stein, J.A.; Shew, J.J. A deliberative research approach to valuing agro-ecosystem services in a worked landscape. Ecosyst. Serv. 2020, 42, 101083. [CrossRef]

151. Song, B.; Robinson, G.M.; Zhou, Z. Agricultural transformation and ecosystem services: A case study from Shaanxi Province, China. Habitat Int. 2017, 69, 114-125. [CrossRef]

152. Dai, J.; Chen, B.; Hayat, T.; Alsaedi, A.; Ahmad, B. Sustainability-based economic and ecological evaluation of a rural biogas-linked agro-ecosystem. Renew. Sustain. Energy Rev. 2015, 41, 347-355. [CrossRef]

153. Zhang, X.H.; Zhang, R.; Wu, J.; Zhang, Y.Z.; Lin, L.L.; Deng, S.H.; Li, L.; Yang, G.; Yu, X.-Y.; Qi, H.; et al. An emergy evaluation of the sustainability of Chinese crop production system during 2000-2010. Ecol. Indic. 2016, 60, 622-633. [CrossRef]

154. Damani, O. Design of Farm Assessment Index (FAI) for a holistic comparison of farming practices: Case of organic and conventional farming systems from two Indian states. Agroecol. Sustain. Food Syst. 2019, 43, 329-357.

155. Fagioli, F.F.; Rocchi, L.; Paolotti, L.; Słowiński, R.; Boggia, A. From the farm to the agri-food system: A multiple criteria framework to evaluate extended multi-functional value. Ecol. Indic. 2017, 79, 91-102. [CrossRef]

156. Fleskens, L.; Duarte, F.; Eicher, I. A conceptual framework for the assessment of multiple functions of agro-ecosystems: A case study of Trás-os-Montes olive groves. J. Rural Stud. 2009, 25, 141-155. [CrossRef] 
157. Hrabák, J.; Konečný, O. Multifunctional agriculture as an integral part of rural development: Spatial concentration and distribution in Czechia. Nor. Geogr. Tidsskr. Nor. J. Geogr. 2018, 72, 257-272. [CrossRef]

158. Marques-Perez, I.; del Río, B.S.G. Identifying functionality of peri-urban agricultural systems: A case study. In Urban agriculture; Samer, M., Ed.; InTech: London, UK, 2016; pp. 61-88.

159. Modernel, P.; Dogliotti, S.; Alvarez, S.; Corbeels, M.; Picasso, V.; Tittonell, P.; Rossing, W.A. Identification of beef production farms in the Pampas and Campos area that stand out in economic and environmental performance. Ecol. Indic. 2018, 89, 755-770. [CrossRef]

160. Nguyen, T.T.; Verdoodt, A.; Van, Y.T.; Delbecque, N.; Tran, T.C.; Van Ranst, E. Design of a GIS and multi-criteria-based land evaluation procedure for sustainable land-use planning at the regional level. Agric. Ecosyst. Environ. 2015, 200, 1-11. [CrossRef]

161. Troiano, S.; Novelli, V.; Geatti, P.; Marangon, F.; Ceccon, L. Assessment of the sustainability of wild rocket (Diplotaxis tenuifolia) production: Application of a multi-criteria method to different farming systems in the province of Udine. Ecol. Indic. 2019, 97, 301-310. [CrossRef]

162. Zhang, Y.; Long, H.; Ma, L.; Ge, D.; Tu, S.; Qu, Y. Farmland function evolution in the Huang-Huai-Hai Plain: Processes, patterns and mechanisms. J. Geogr. Sci. 2018, 28, 759-777. [CrossRef]

163. Li, J.G.; Ou, M.H.; Zhang, X.J.; Zang, J.M.; Gao, Y.M.; Zhang, Q.J. Reconstruction of cultivated land resources value system and its evaluation: A case study of Qingdao. J. Nat. Resour. 2009, 24, 1870-1877. (In Chinese)

164. Marques-Perez, I.; Segura, B. Integrating social preferences analysis for multifunctional peri-urban farming in planning. An application by multi-criteria analysis techniques and stakeholders. Agroecol. Sustain. Food Syst. 2018, 42, 1029-1057. [CrossRef]

165. Schaller, L.; Targetti, S.; Villanueva, A.J.; Zasada, I.; Kantelhardt, J.; Arriaza, M.; Bal, T.; Fedrigotti, V.B.; Giray, F.H.; Häfner, K.; et al. Agricultural landscapes, ecosystem services and regional competitiveness-Assessing drivers and mechanisms in nine European case study areas. Land Use Policy 2018, 76, 735-745. [CrossRef]

166. Fagerholm, N.; Eilola, S.; Kisanga, D.; Arki, V.; Käyhkö, N. Place-based landscape services and potential of participatory spatial planning in multifunctional rural landscapes in Southern highlands, Tanzania. Landsc. Ecol. 2019, 34, 1769-1787. [CrossRef]

167. Fagerholm, N.; Torralba, M.; Moreno, G.; Girardello, M.; Herzog, F.; Aviron, S.; Burgess, P.; Crous-Duran, J.; Ferrero-Domínguez, N.; Graves, A.; et al. Cross-site analysis of perceived ecosystem service benefits in multi-functional landscapes. Glob. Environ. Chang. 2019, 56, 134-147. [CrossRef]

168. García-Nieto, A.P.; Quintas-Soriano, C.; García-Llorente, M.; Palomo, I.; Montes, C.; Martín-López, B. Collaborative mapping of ecosystem services: The role of stakeholders' profiles. Ecosyst. Serv. 2015, 13, 141-152. [CrossRef]

169. Kivinen, S.; Vartiainen, K.; Kumpula, T. People and post-mining environments: PPGIS mapping of landscape values, knowledge needs, and future perspectives in northern Finland. Land 2018, 7, 151. [CrossRef]

170. Verbrugge, L.; Buchecker, M.; Garcia, X.; Gottwald, S.; Müller, S.; Præstholm, S.; Olafsson, A.S. Integrating sense of place in planning and management of multifunctional river landscapes: Experiences from five European case studies. Sust. Sci. 2019, 14, 669-680. [CrossRef]

171. Dwyer, J.; Short, C.J.; Berriet-Solliec, M.; Gael-Lataste, F.; Pham, H.V.; Affleck, M.; Courtney, P.; Déprès, C. Public Goods and Ecosystem Services from Agriculture and Forestry-A Conceptual Appro; PEGASUS: Brussels, Belgium, 2015.

172. Pronyk, P.; Schaefer, J.; Somers, M.A.; Heise, L. Evaluating structural interventions in public health: Challenges, options and global best practice. In Structural Approaches in Public Health; Pronyk, P., Schaefer, J., Somers, M.-A., Heise, L., Eds.; Taylor and Francis: Abingdon, UK; New York, NY, USA, 2013; pp. 187-205.

173. Fang, Y.G.; Liu, J.S. Diversified agriculture and rural development in China based on multifunction theory: Beyond modernization paradigm. Acta Geogr. Sin. 2015, 70, 257-270.

174. Moon, W.; Griffith, J.W. Assessing holistic economic value for multifunctional agriculture in the US. Food Policy 2011, 36, 455-465. [CrossRef]

175. Heringa, P.W.; Van der Heide, C.M.; Heijman, W.J. The economic impact of multifunctional agriculture in Dutch regions: An input-output model. Njas-Wagening. J. Life Sci. 2013, 64, 59-66. [CrossRef]

176. Mölders, T. Multifunctional agricultural policies: Pathways towards sustainable rural development? Int. J. Sociol. Agric. Food 2014, 21, 97-114. 
177. Boyle, K.J. Contingent valuation in practice. In A Primer on Nonmarket Valuation; Champ, P.A., Boyle, K.J., Brown, T.C., Eds.; Springer: Dordrecht, The Netherlands, 2017; pp. 83-131.

178. Cucchia, T. Contingent valuation. In Handbook of Cultural Economics, 3rd ed.; Towse, R., Ed.; Edward Elgar Publishing: Cheltenham, UK, 2020; pp. 90-99.

179. Kallas, Z.; Gómez-Limón, J.A.; Hurlé, J.B. Decomposing the value of agricultural multifunctionality: Combining contingent valuation and the analytical hierarchy process. J. Agric. Econ. 2007, 58, 218-241. [CrossRef]

180. Howley, P.; Hynes, S.; Donoghue, C.O. Countryside preferences: Exploring individuals' willingness to pay for the conservation of the traditional farm landscape. Landsc. Res. 2012, 37, 703-719. [CrossRef]

181. Bennett, J.; Van Bueren, M.; Whitten, S. Estimating society's willingness to pay to maintain viable rural communities. Aust. J. Agric. Resour. Econ. 2004, 48, 487-512. [CrossRef]

182. Bergstrom, J.C.; Ready, R.C. What have we learned from over 20 years of farmland amenity valuation research in North America? Rev. Agric. Econ. 2009, 31, 21-49. [CrossRef]

183. Hellerstein, D.; Nickerson, C.; Cooper, J.C.; Feather, P.; Gadsby, D.; Mullarkey, D.; Tegene, A. Farmland protection: The role of public preferences for rural amenities. Econ. Res. Serv ERR 2002, 183.

184. Moon, W.; Chang, J.B.; Asirvatham, J. Measuring public preferences for multifunctional attributes of agriculture in the United States. J. Agric. Appl. Econ. 2017, 49, 273-295. [CrossRef]

185. Dahal, R.P.; Grala, R.K.; Gordon, J.S.; Petrolia, D.R.; Munn, I.A. Estimating the willingness to pay to preserve waterfront open spaces using contingent valuation. Land Use Policy 2018, 78, 614-626. [CrossRef]

186. Grala, R.K.; Tyndall, J.C.; Mize, C.W. Willingness to pay for aesthetics associated with field windbreaks in Iowa, United States. Landsc. Urban Plan. 2012, 108, 71-78. [CrossRef]

187. Mutandwa, E.; Grala, R.K.; Petrolia, D.R. Estimates of willingness to accept compensation to manage pine stands for ecosystem services. For. Policy Econ. 2019, 102, 75-85. [CrossRef]

188. Gao, Q.; Ao, C.L.; Chen, H.G.; Tong, R. Spatial differentiation research of non-use value WTP based on the residents' ecological cognition: Taking the Sanjiang Plain as a case. Acta Ecol. Sin. 2014, 34, 1851-1859.

189. Byrnes, J.E.; Gamfeldt, L.; Isbell, F.; Lefcheck, J.S.; Griffin, J.N.; Hector, A.; Carindale, B.J.; Hooper, D.U.; Dee, L.E.; Duffy, J.E. Investigating the relationship between biodiversity and ecosystem multifunctionality: Challenges and solutions. Methods Ecol. Evol. 2014, 5, 111-124. [CrossRef]

190. Jin, L.; Sun, K.; He, H.; Zhou, Y. Research advances in habitat suitability index model. Chin. J. Ecol. 2008, 27, 841-846. (In Chinese)

191. Yi, Y.; Cheng, X.; Zhou, J. Research progress in habitat suitability assessment methods. Ecol. Environ. Sci. 2013, 22, 887-893. (In Chinese)

192. Duflot, R.; Avon, C.; Roche, P.; Bergès, L. Combining habitat suitability models and spatial graphs for more effective landscape conservation planning: An applied methodological framework and a species case study. J. Nat. Conserv. 2018, 46, 38-47. [CrossRef]

193. Latifiana, K.; Danoedoro, P.; As-Singkily, M.; Cahyana, A.N. Spatial habitat suitability modeling of the Roti snake-necked turtle (Chelodina mccordi) based on Landsat-8 imagery and GIS. In Proceedings of the 4th International Conference on Science and Technology (ICST), Yogyakarta, Indonesia, 7-8 August 2018; pp. 1-6.

194. Lewis, N.S.; Fox, E.W.; DeWitt, T.H. Estimating the distribution of harvested estuarine bivalves with natural-history-based habitat suitability models. Estuarine, Coastal Shelf Sci. 2019, 219, 453-472. [CrossRef] [PubMed]

195. Martinig, A.R. Habitat suitability modeling for mink passage activity: A cautionary tale. J. Wildl. Manag. 2017, 81, 1439-1448. [CrossRef]

196. Steenweg, R.; Hebblewhite, M.; Gummer, D.; Low, B.; Hunt, B. Assessing potential habitat and carrying capacity for reintroduction of plains bison (Bison bison bison) in Banff National Park. PLoS ONE 2016, 11, e0150065. [CrossRef] [PubMed]

197. Tadesse, S.A.; Kotler, B.P. Habitat quality assessed with a habitat suitability model and habitat selection revealed by isodar analysis for the Mountain Nyala (Tragelaphus buxtoni) in Munessa, Ethiopia. Asian J. Appl. Sci. 2016, 4. Available online: https://python.zzx.us/index.php/AJAS/article/view/3838 (accessed on 1 August 2020).

198. Zubizarreta-Gerendiain, A.; Pukkala, T.; Peltola, H. Effect of wind damage on the habitat suitability of saproxylic species in a boreal forest landscape. J. For. Res. 2019, 30, 879-889. [CrossRef] 
199. Aneseyee, A.B.; Noszczyk, T.; Soromessa, T.; Elias, E. The InVEST habitat quality model associated with land use/cover changes: A qualitative case study of the Winike Watershed in the Omo-Gibe Basin, Southwest Ethiopia. Remote Sens. 2020, 12, 1103. [CrossRef]

200. Kija, H.K.; Ogutu, J.O.; Mangewa, L.J.; Bukombe, J.; Verones, F.; Graae, B.; Kideghesho, J.T.; Said, M.Y.; Nzunda, E.F. Spatio-temporal changes in wildlife habitat quality in the Greater Serengeti ecosystem. Sustainability 2020, 12, 2440. [CrossRef]

201. Liu, Y.; Zhou, Y.; Du, Y. Study on the spatio-Temporal patterns of habitat quality and its terrain gradient effects of the middle of the Yangtze River Economic Belt based on InVEST model. Resour. Environ. Yangtze Basin 2019, 28, 2429-2440. (In Chinese)

202. Sallustio, L.; De Toni, A.; Strollo, A.; Di Febbraro, M.; Gissi, E.; Casella, L.; Geneletti, D.; Munafo, M.; Vizzarri, M.; Marchetti, M. Assessing habitat quality in relation to the spatial distribution of protected areas in Italy. J. Environ. Manag. 2017, 201, 129-137. [CrossRef] [PubMed]

203. Zhang, X.; Zhou, J.; Li, M. Analysis on spatial and temporal changes of regional habitat quality based on the spatial pattern reconstruction of land use. Acta Geogr. Sin. 2020, 75, 160-178.

204. Zhong, L.; Wang, J. Evaluation on effect of land consolidation on habitat quality based on InVEST model. Trans. Chin. Soc. Agric. Eng. 2017, 33, 250-255. (In Chinese)

205. Phillips, S.J.; Anderson, R.P.; Schapire, R.E. Maximum entropy modeling of species geographic distributions. Ecol. Model. 2006, 190, 231-259. [CrossRef]

206. Ma, B.; Sun, J. Predicting the distribution of Stipa purpurea across the Tibetan Plateau via the MaxEnt model. BMC Ecol. 2018, 18, 10. [CrossRef]

207. Qiao, H.; Hu, J.; Huang, J. Theoretical basis, future directions, and challenges for ecological niche models. Sci. Sin. Vitae 2013, 43, 915-927. (In Chinese) [CrossRef]

208. Warren, D.L.; Wright, A.N.; Seifert, S.N.; Shaffer, H.B. Incorporating model complexity and spatial sampling bias into ecological niche models of climate change risks faced by 90 California vertebrate species of concern. Divers. Distrib. 2014, 20, 334-343. [CrossRef]

209. Alfaya, P.; Casanovas, J.G.; Lobón-Rovira, J.; Matallanas, B.; Cruz, A.; Arana, P.; Alonso, G. Using MaxEnt algorithm to assess habitat suitability of a potential Iberian lynx population in central Iberian Peninsula. Community Ecol. 2019, 20, 266-276. [CrossRef]

210. Almasieh, K.; Zoratipour, A.; Negaresh, K.; Hasanzadeh, K.D. Habitat quality modelling and effect of climate change on the distribution of Centaurea pabotii in Iran. Span. J. Agric. Res. 2018, 16, 5. [CrossRef]

211. Healy, A.; Lippitt, C.D.; Phillips, D.; Lane, M. A comparison of suitability models to identify prehistoric agricultural fields in western New Mexico. J. Archaeol. Sci. Rep. 2017, 11, 427-434. [CrossRef]

212. Khosravi, R.; Hemami, M.R.; Cushman, S.A. Multi-scale niche modeling of three sympatric felids of conservation importance in central Iran. Landsc. Ecol. 2019, 34, 2451-2467. [CrossRef]

213. Liu, Z.; Gao, H.; Teng, L.; Su, Y.; Wang, X.; Kong, F. Habitat suitability assessment of blue sheep in Helan Mountain based on MAXENT modeling. Acta Ecol. Sin. 2013, 33, 7243-7249. (In Chinese)

214. Mammola, S.; Milano, F.; Vignal, M.; Andrieu, J.; Isaia, M. Associations between habitat quality, body size and reproductive fitness in the alpine endemic spider Vesubia jugorum. Glob. Ecol. Biogeogr. 2019, 28, 1325-1335. [CrossRef]

215. Millennium Ecosystem Assessment (MEA). Ecosystems and Human Well-Being: A Framework for Assessment; Island Press: Washington, DC, USA, 2005.

216. Assandri, G.; Bogliani, G.; Pedrini, P.; Brambilla, M. Beautiful agricultural landscapes promote cultural ecosystem services and biodiversity conservation. Agric. Ecosyst. Environ. 2018, 256, 200-210. [CrossRef]

217. Danley, B.; Widmark, C. Evaluating conceptual definitions of ecosystem services and their implications. Ecol. Econ. 2016, 126, 132-138. [CrossRef]

218. Helm, D. Taking natural capital seriously. Oxf. Rev. Econ. Policy 2014, 30, 109-125. [CrossRef]

219. Huang, J.; Tichit, M.; Poulot, M.; Darly, S.; Li, S.; Petit, C.; Aubry, C. Comparative review of multifunctionality and ecosystem services in sustainable agriculture. J. Environ. Manag. 2015, 149, 138-147. [CrossRef]

220. Rodríguez-Robayo, K.J.; Merino-Perez, L. Contextualizing context in the analysis of payment for ecosystem services. Ecosyst. Serv. 2017, 23, 259-267. [CrossRef]

221. Robinson, D.A.; Fraser, I.; Dominati, E.; Davíðsdóttir, B.; Jónsson, J.O.G.; Jones, L.; Jones, S.B.; Tuller, M.; Lebron, I.; Bristow, K.L.; et al. On the value of soil resources in the context of natural capital and ecosystem service delivery. Soil Sci. Soc. Am. J. 2014, 78, 685-700. [CrossRef] 
222. Zhou, Z.; Robinson, G.M.; Song, B. 'Trade-offs in ecosystem services: The agro-ecosystem functional spectrum and experimental research'. Ecol. Indic. 2019, 106, 105536. [CrossRef]

223. Andersen, P.S.; Vejre, H.; Dalgaard, T.; Brandt, J. An indicator-based method for quantifying farm multifunctionality. Ecol. Indic. 2013, 25, 166-179. [CrossRef]

224. Fagerholm, N.; Käyhkö, N.; Ndumbaro, F.; Khamis, M. Community stakeholders' knowledge in landscape assessments-Mapping indicators for landscape services. Ecol. Indic. 2012, 18, 421-433. [CrossRef]

225. Peng, J.; Liu, Z.C.; Liu, Y.X. Research progress on assessing multi-functionality of agriculture. Chin. J. Agric. Resour. Reg. Plan. 2014, 35, 1-8.

226. Cheng, X.; Van Damme, S.; Li, L.; Uyttenhove, P. Evaluation of cultural ecosystem services: A review of methods. Ecosyst. Serv. 2019, 37, 100925. [CrossRef]

227. Miao, J.; Yang, W.; Yang, B.; Ma, Y.; Huang, G. Evaluating the ecosystem services of Chongyi Hakka terraces in Gannan, Jiangxi Province. J. Nat. Resour. 2016, 31, 1817-1831.

228. Gomezelj, D.O.; Mihalič, T. Destination competitiveness-Applying different models, the case of Slovenia. Tour. Manag. 2008, 29, 294-307. [CrossRef]

229. Sowińska-Świerkosz, B. Review of cultural heritage indicators related to landscape: Types, categorisation schemes and their usefulness in quality assessment. Ecol. Indic. 2017, 81, 526-542. [CrossRef]

230. Haines-Young, R.; Potschin, M. CICES Version 4: Response to Consultation; Centre for Environmental Management, University of Nottingham: Nottingham, UK, 2012.

231. Casalegno, S.; Inger, R.; DeSilvey, C.; Gaston, K.J. Spatial covariance between aesthetic value and other ecosystem services. PLoS ONE 2013, 8, e68437. [CrossRef]

232. Yoshimura, N.; Hiura, T. Demand and supply of cultural ecosystem services: Use of geotagged photos to map the aesthetic value of landscapes in Hokkaido. Ecosyst. Serv. 2017, 24, 68-78. [CrossRef]

233. Sherrouse, B.C.; Semmens, D.J. Social Values for Ecosystem Services, version 3.0 (SolVES 3.0): Documentation and User Manual; US Geological Survey: Washington, DC, USA, 2015; p. 65.

234. Tang, Y.; Mu, H.Z. Literature review of value accounting for arable land in China. Chin. J. Agric. Resour. Reg. Plan. 2014, 35, 73-79.

235. Di Fazio, S.; Modica, G. Historic rural landscapes: Sustainable planning strategies and action criteria. The Italian experience in the global and European context. Sustainability 2018, 10, 3834. [CrossRef]

236. Modica, G.; Vizzari, M.; Pollino, M.; Fichera, C.R.; Zoccali, P.; Di Fazio, S. Spatio-temporal analysis of the urban-rural gradient structure: An application in a Mediterranean mountainous landscape (Serra San Bruno, Italy). Earth Syst. Dyn. 2012, 3, 263-279. [CrossRef]

237. Loures, L.; Loures, A.; Nunes, J.; Panagopoulos, T. Landscape valuation of environmental amenities throughout the application of direct and indirect methods. Sustainability 2015, 7, 794-810. [CrossRef]

238. Wood, R.; Handley, J. Landscape dynamics and the management of change. Lands. Res. 2001, 26, 45-54. [CrossRef]

239. Fairclough, G.; Herlin, I.S.; Swanwick, C. Routledge Handbook of Landscape Character Assessment: Current Approaches to Characterisation and Assessment; Routledge: London, UK, 2018.

240. Lanucara, S.; Praticó, S.; Modica, G. Harmonization and interoperable sharing of multi-temporal geospatial data of rural landscapes. In New Metropolitian Perspectives: Local Knowledge and Innovation Dynamics Towards Territory Attractiveness Through the Implementation of Horizon; Calabró, F., Della Spina, L., Bevilacqua, C., Eds.; Springer: Cham, Germany, 2019; pp. 51-59.

241. Della Spina, L. Scenarios for sustainable valorisation of cultural landscape as driver of loca; development. In New Metropolitian Perspectives: Local Knowledge and Innovation Dynamics Towards Territory Attractiveness Through the Implementation of Horizon; Calabró, F., Della Spina, L., Bevilacqua, C., Eds.; Springer: Cham, Germany, 2019; pp. 113-122.

242. Morano, P.; Tajani, F. Saving soil and financial feasibility. A model to support public-private partnerships in the regeneration of abandoned areas. Land Use Policy 2018, 73, 40-48. [CrossRef]

243. Liu, Y.; Liu, Y.S.; Guo, L.Y. Spatio-temporal differentiation of county multi-functions along the Bohai Rim in China. Acta Sci. Nat. Univ. Pekin. 2012, 48, 998-1008.

244. Liu, Z.; Robinson, G.M. Residential development in the peri-urban fringe: The example of Adelaide, South Australia. Land Use Policy 2016, 57, 179-192. [CrossRef]

245. Moroney, J.; Castellano, R.S. Farmland loss and concern in the Treasure Valley. Agric. Hum. Values 2018, 35, 529-536. [CrossRef] 
246. Yu, M.; Yang, Y.; Chen, F.; Zhu, F.; Qu, J.; Zhang, S. Response of agricultural multifunctionality to farmland loss under rapidly urbanizing processes in Yangtze river delta, China. Sci. Total Environ. 2019, 666, 1-11. [CrossRef]

247. Ren, Y.; Lu, Y.; Long, H. The study on non-agricultural transformation co-evolution characteristics of population-land-Industry: Case study of the Bohai Rim in China. Geogr. Res. 2015, 34, 475-486.

248. Wu, Z.; Wei, C.; Ding, S. Research on the social security function of cultivated land in a hilly-mountainous region. Resour. Sci. 2013, 35, 95-103.

249. Ye, S.; Li, S. Assessment on the social value of cultivated land resources-Taking Xi'an as an example. Chin. J. Agric. Resour. Reg. Plan. 2013, 2, 27-32. (In Chinese)

250. Fagerholm, N.; Martín-López, B.; Torralba, M.; Oteros-Rozas, E.; Lechner, A.M.; Bieling, C.; Stahl Olafsson, A.; Albert, C.; Raymond, C.M.; Garcia-Martin, M.; et al. Perceived contributions of multifunctional landscapes to human well-being: Evidence from 13 European sites. People Nat. 2020, 2, 217-234. [CrossRef]

251. Eilola, S.; Fagerholm, N.; Mäki, S.; Khamis, M.; Käyhkö, N. Realization of participation and spatiality in participatory forest management - a policy-practice analysis from Zanzibar, Tanzania. J. Environ. Plan. Manag. 2015, 58, 1242-1269. [CrossRef]

252. García-Martín, M. Landscape values in Europe: Insights from participatory mapping research. In Landscape Values: Place and Praxis; Collins, T., Kindermann, G., Newman, C., Cronin, N., Eds.; Centre for Landscape Studies, NUI Galway: Galway, Ireland, 2016; pp. 127-134.

253. West, S.; Haider, L.J.; Masterson, V.; Enqvist, J.P.; Svedin, U.; Tengö, M. Stewardship, care and relational values. Curr. Opin. Environ. Sustain. 2018, 35, 30-38. [CrossRef]

254. Chapman, M.; Satterfield, T.; Chan, K.M. When value conflicts are barriers: Can relational values help explain farmer participation in conservation incentive programs? Land Use Policy 2019, 82, 464-475. [CrossRef]

255. O'Connor, S.; Kenter, J.O. Making intrinsic values work; integrating intrinsic values of the more-than-human world through the Life Framework of Values. Sustain. Sci. 2019, 14, 1247-1265. [CrossRef]

256. Piccolo, J.J. Intrinsic values in nature: Objective good or simply half of an unhelpful dichotomy? J. Nat. Conserv. 2017, 37, 8-11. [CrossRef]

257. Cox, M. The pathology of command and control: A formal synthesis. Ecol. Soc. 2016, 21, 1-8. [CrossRef]

258. Milne, S.; Niesten, E. Direct payments for biodiversity conservation in developing countries: Practical insights for design and implementation. Oryx 2009, 43, 530-541. [CrossRef]

259. Patton, M.; Kostov, P.; McErlean, S.; Moss, J. Assessing the influence of direct payments on the rental value of agricultural land. Food Policy 2008, 33, 397-405. [CrossRef]

260. Klain, S.C.; Olmsted, P.; Chan, K.M.; Satterfield, T. Relational values resonate broadly and differently than intrinsic or instrumental values, or the New Ecological Paradigm. PLoS ONE 2017, 12, e0183962. [CrossRef] [PubMed]

261. Allen, K.E.; Quinn, C.E.; English, C.; Quinn, J.E. Relational values in agroecosystem governance. Curr. Opin. Environ. Sustain. 2018, 35, 108-115. [CrossRef]

262. Chan, K.M.; Balvanera, P.; Benessaiah, K.; Chapman, M.; Díaz, S.; Gómez-Baggethun, E.; Gould, R.; Hannahs, N.; Jax, K.; Klain, S.; et al. Opinion: Why protect nature? Rethinking values and the environment. Proc. Natl. Acad. Sci. USA 2016, 113, 1462-1465. [CrossRef]

263. Chan, K.M.; Gould, R.K.; Pascual, U. Editorial overview: Relational values: What are they, and what's the fuss about? Curr. Opin. Environ. Sustain. 2018, 35, A1-A7. [CrossRef]

264. Lokhorst, A.M.; Hoon, C.; le Rutte, R.; de Snoo, G. There is an I in nature: The crucial role of the self in nature conservation. Land Use Policy 2014, 39, 121-126. [CrossRef]

265. Maybery, D.; Crase, L.; Gullifer, C. Categorising farming values as economic, conservation and lifestyle. J. Econ. Psychol. 2005, 26, 59-72. [CrossRef]

266. Mould, S.; Fryirs, K.; Howitt, R. The importance of relational values in river management: Understanding enablers and barriers for effective participation. Ecol. Soc. 2020, 25. [CrossRef]

267. Fielke, S.J.; Wilson, G.A. Multifunctional intervention and market rationality in agricultural governance: A comparative study of England and South Australia. GeoJournal 2017, 82, 1067-1083. [CrossRef]

268. Leakey, R.R.B.; Prabhu, R. Towards multifunctional agriculture-An African initiative. In Multifunctional Agriculture: Achieving Sustainable Development in Africa; Academic Press: London, UK, 2017; pp. 395-416.

269. Bardsley, D.K.; Palazzo, E.; Stringer, R. What should we conserve? Farmer narratives on biodiversity values in the McLaren Vale, South Australia. Land Use Policy 2019, 83, 594-605. [CrossRef] 
270. Fouilleux, E.; Bricas, N.; Alpha, A. 'Feeding 9 billion people': Global food security debates and the productionist trap. J. Eur. Public Policy 2017, 24, 1658-1677. [CrossRef]

271. Candel, J.J.; Biesbroek, R. Policy integration in the EU governance of global food security. Food Secur. 2018, 10, 195-209. [CrossRef]

272. Robinson, G.M. New frontiers in agricultural geography: Transformations, food security, land grabs and climate change. Bage Boletín De La Asoc. De Geógrafos Españoles 2018, 78, 1-48. [CrossRef]

273. Rivaroli, S.; Bertazzoli, A.; Ghelfi, R.; Laghi, A. Multifunctional farming in Emilia-Romagna region: An analysis through agricultural census data. New Medit. 2016, 15, 37-44.

274. Jordan, N.R.; Mulla, D.J.; Slotterback, C.; Runck, B.; Hays, C. Multifunctional agricultural watersheds for climate adaptation in Midwest USA: Commentary. Renew. Agric. Food Syst. 2018, 33, 292. [CrossRef]

(C) 2020 by the authors. Licensee MDPI, Basel, Switzerland. This article is an open access article distributed under the terms and conditions of the Creative Commons Attribution (CC BY) license (http://creativecommons.org/licenses/by/4.0/). 